\title{
Maize Myosins: Diversity, Localization, and Function
}

\author{
Liyun Liu, ${ }^{1}$ Juhua Zhou, ${ }^{2}$ and Thomas C. Pesacreta ${ }^{3 *}$ \\ ${ }^{1}$ Biological Laboratories, Harvard University, Cambridge, Massachusetts \\ ${ }^{2}$ Department of Pharmacology, Baylor College of Medicine, Houston, Texas \\ ${ }^{3}$ Microscopy Center, University of Louisiana at Lafayette
}

\begin{abstract}
This first analysis of monocotyledon myosin genes showed that at least five genes, one of which was probably spliced to yield two isoforms, were expressed in maize (Zea mays L.). The complete coding sequence of ZMM1 was determined, as were most of the sequences of two other myosin cDNAs (ZMM2 and ZMM3). ZMM1 and ZMM2 belonged to myosin class XI while ZMM3 was in class VIII. ZMM1 was abundantly expressed in leaves, roots, coleoptiles, and stems. ZMM3 showed a similar distribution but was expressed poorly in pollen. ZMM2 was predominantly expressed in seeds and may be part of a suite of cytoskeletal proteins in reproductive tissues. Phylogenetic analysis suggested that the origin of myosin classes VIII and XI predated that of angiosperms. Immunofluorescence studies using M11L1, a myosin XI antibody specific for the exposed loop 1 head region of myosin, indicated that myosin XI occurred in the cytoplasm of all root tip cells. The highest concentration of myosin XI was in the differentiating epidermal cells. In dividing cells, myosin XI was present near the cytokinetic apparatus at approximately the same concentration seen in other portions of the cytoplasm. Western blot analysis of subcellular fractions indicated that myosin $\mathrm{XI}$ was concentrated in mitochondria and low-density membranes. Cell Motil. Cytoskeleton 48:130-148, 2001. @ 2001 Wiley-Liss, Inc.
\end{abstract}

Key words: cell membranes; cytokinesis; cytoskeleton; immunocytochemistry; root

\section{INTRODUCTION}

The intricate and extensive plant cytoskeleton consists, in part, of actin microfilaments and associated proteins including myosin [see review by Staiger and Lloyd, 1991). These proteins are involved in diverse processes such as pollen tube development [Pieson and Cresti, 1992; Cai et al., 1996], cell division [Schmidt and Lambert, 1990], and cyclosis [Asada and Collings, 1997; Williamson, 1993]. The first immunocytochemical study of plant myosin [Parke et al., 1986] showed that a monoclonal antibody raised against mouse protein strongly labeled the cytokinetic phragmoplast.

Myosins are specialized mechanochemical molecular motors that can act as coupling agents between membranes and actin. The number of known myosins has increased steadily since the early 1970s when non-muscle myosins were discovered [see Pollard and Korn, 1973 and references therein]. At present, it is thought that the myosin superfamily may contain as many as 15 classes, although some "classes" contain only a single member [for recent articles that describe the diversity within the myosin superfamily see Cope et al., 1996; Mermall et al., 1998; Sellers, 2000]. There is however, only a limited understanding of the biochemical complexity of plant myosin and its diverse functions in motility.

Protein characterization and immunohistochemistry have been used to study myosin in a wide range of higher plant species [e.g., maize, Nehez et al., 1985; Radford and White, 1998; onion, Parke et al., 1986, Liebe and Quader, 1994; tomato, Vahey et al., 1982; tobacco, Miller et al., 1995; lily, Yokota and Shimmen,

Contract grant sponsor: State of Louisiana Educational Quality Support Fund; Contract grant number: R-637.

*Correspondence to: Dr. Thomas C. Pesacreta, PO Box 42451, 300 E. St Mary Blvd., University of Louisiana, Lafayette, LA 70504.

E-mail: tcp9769@louisiana.edu

Received 30 May 2000; Accepted 27 September 2000 
1994; pea, Ma and Yen, 1989; as well as algae, e.g., Chara, Yamamoto et al., 1995; and Chlamydomonas, La Claire et al., 1995]. Myosin epitopes have been localized to vesicles [Tirlapur et al., 1995], microsomes [Reichelt et al., 1999], chloroplasts [La Claire et al., 1995], plasmodesmata, nuclei, plasma membrane [Radford and White, 1998] and on the surface of generative pollen cells [Miller et al., 1995]. These studies show that plants express multiple myosins or myosin-like proteins with molecular weights that extend over a large range of 90 to $220 \mathrm{kDa}$. This range is similar to that known to exist in non-plant species [Mooseker and Cheney, 1995]. Taken as a whole, these studies suggest that a complex array of myosins, each with a specific function and attached to a specific region within the cell, exists in plant cells.

Several plant myosins have been sequenced. These sequences code for proteins with a range of deduced molecular weights that is much more restricted than that suggested by the above-mentioned Western blot data. Data are available for two ferns, Anemia and Azolla [Moepps et al., 1993; Plazinski et al., 1997], and two algae, Acetabularia and Chara (Vugrek and Menzel, unpublished data) [Kashiyama et al., 2000]. In angiosperms, our knowledge of myosin genes is limited to two dicotyledons, Arabidopsis thaliana, where five cDNA sequences of myosin genes have been published [Knight and Kendrick-Jones, 1993; Kinkema and Schiefelbein, 1994; Kinkema et al., 1994], and Helianthus annuus, where five myosin cDNA clones have recently been sequenced (Vugrek and Menzel, unpublished data).

In order to explicate the diversity of plant myosins, we have analyzed myosin genes of Zea mays L., a monocotyledon species that is phylogenetically distant from other plants that have been previously studied. Here, we present several different myosin cDNA sequences with predicted molecular weights for the deduced proteins in the 125 to $175 \mathrm{kDa}$ range. There is good evidence for the existence of at least two subclasses within class XI. The head and the tail regions of maize myosin genes seem to have evolved in the context of different functional constraints. We also show that myosin XI is not concentrated near the cytokinetic phragmoplast.

\section{MATERIALS AND METHODS}

\section{Plant Material}

Seeds of two maize (Zea mays L., Panicoideae) varieties, "Merit" and the B73 inbred line, were soaked in tap water and germinated on wet paper towels for 3-6 days. Roots and coleoptiles were sampled 3 days after germination while leaves were collected after 6-8 days. The B73 line was used for isolation of cDNA and genomic DNA. The Merit line was used for isolation of RNA because seed for this line was more readily available. Pollen was harvested from greenhouse-grown Merit plants, but growing corn to the "ear" stage was difficult so fresh ears were purchased from a local store for analysis of fresh kernels and silks.

\section{Isolation of Genomic DNA, Total RNA, and mRNA From Maize}

Maize genomic DNA was isolated from shoots essentially as described by Dellaporta et al. [1983]. An average yield of $120 \mu \mathrm{g}$ per gram fresh weight of etiolated coleoptiles was obtained. Total RNA from leaves, stems (hypocotyls), and coleoptiles was prepared using the protocol of Burgos et al. [1995]. On average, one gram of fresh tissue yielded approximately $250 \mu \mathrm{g}$ of total RNA. Total RNA was isolated from roots using the acid guanidine thiocyanate-phenol-chloroform (AGPC) method [Chomczynski and Sacchi, 1987]. Total RNA was isolated from fresh kernels, pollen, and silks according to Or et al. [1991]. The yield of total RNA from $1.5 \mathrm{~g}$ of seeds was approximately $290 \mathrm{mg}$. Poly $\left(\mathrm{A}^{+}\right) \mathrm{mRNA}$ was purified from total RNA using a magnetic bead kit (Promega, Madison, WI). From maize coleoptiles the yield of poly $\mathrm{A}^{+}$RNA was approximately $0.5 \%$ of total RNA.

\section{RT-PCR}

Three different classes of non-plant myosin were aligned and four highly conserved myosin head amino acid sequences were chosen for designing degenerate primers.

$$
\begin{gathered}
N \_ \text {Primer } Z(183) \rightarrow \text { Primer } E(234) \rightarrow- \\
\text { GESGAGK } \\
\leftarrow \text { Primer B }(285) \_ \text {Primer D }(486) \_ \\
\text {ERNYHIFYQ } \\
\text { FEQLCIN }
\end{gathered}
$$

Arrows pointing right designate sense primers. Arrows pointing left designate antisense primers. Numbers indicate number of amino acid residues between the $\mathrm{N}$ terminal end of myosin and the primer. Numbering is based on bovine brush border myosin I (BBI, GenBank no. CAA80476) [Reizes et al., 1994]. Below each primer is the consensus amino acid sequence used to design the primer. The consensus amino acid sequences were derived from analysis of bovine brush border myosin I gene (BBI, GenBank no. CAA80476) [Reizes et al., 1994], Dictyostelium myosin II (Dic II, GenBank no. P08799) [Warrick and Spudich, 1987], chicken muscle myosin II (Ggmyo II, GenBank no. P13538) [Hayashida et al., 
1991], and yeast myosin V (ScMyo4, GenBank no. P32492) [Haarer et al., 1994] (data not shown).

The nucleotide sequence for each primer was as follows with alternate choices for each position shown in parentheses:

Primer B (antisense): 5'-TG(GA)TA(GA)AATAT(GA)TG(GA)TA(GA)TTTCT(TC)TC-3';

Primer D (antisense): 5'-AGTTGATGCA(GC)AG(TC)TG(CT)TC(GA)AA-3';

Primer E (sense): 5'-GC(CA)TT(CT)GG(TC)AA(CT)GC(CA)AA(GA)AC-3';

Primer $Z$ (sense): 5-'GGTGA(AG)TCTGG(AT)GC(TA)GGTAA(GA)AC-3';

First strand cDNA was synthesized at $42^{\circ} \mathrm{C}$ for $1 \mathrm{~h}$ from $5 \mu \mathrm{m}$ of total RNA with a mixture of oligo-dT and random hexamers using AMV reverse transcriptase (Invitrogen, Carlsbad, CA). PCR products were cloned into pCRII (Invitrogen).

\section{Plasmid Preparation}

Plasmid mini-preps were prepared using the protocol of Ausubel et al. [1988]; 0.5-1 ml of plasmid DNA (50-100 ng) was used for each restriction enzyme digestion or thermocycling DNA sequencing reaction. Largescale plasmid preparation was performed as described by Wang et al. [1994].

\section{Isolating and Radiolabeling DNA Fragments From Agarose Gels}

DNA inserts were released by cutting plasmids with appropriate restriction enzymes at a ratio of $1 \mu \mathrm{g} / \mathrm{ml}$ per unit enzyme. Inserts were isolated by elution from agarose gels and purification with Gene Clean II (Bio 101, Vista, CA). DNA fragments for hybridization were labeled to high specific activity $\left(>1 \times 10^{9} \mathrm{cpm} / \mathrm{mg}\right)$ with ${ }^{32} \mathrm{P}-\mathrm{dCTP}$ using a Megaprime DNA labeling kit (Amersham, Piscataway, NJ). For most DNA fragments, the products of the labeling reaction could be used directly without any purification. If necessary, the probe was purified using gel filtration on a spin column [Sambrook et al., 1989].

\section{DNA Gel Blot Analysis}

Genomic DNA $(10 \mu \mathrm{g})$ was digested in a $50 \mu \mathrm{l}$ reaction volume in $4 \mathrm{mM}$ spermidine and $20 \mathrm{U}$ of restriction enzyme. For analysis of restriction fragment patterns, 5 to $10 \mu \mathrm{g}$ of DNA were loaded in each lane. The restriction fragments were separated on $0.8 \%$ agarose gels with $1 \times$ TAE $(40 \mathrm{mM}$ Tris, $\mathrm{pH} 7.2,20 \mathrm{mM} \mathrm{Na}$ acetate, $1 \mathrm{mM}$ EDTA) buffer in the presence of 0.5 $\mu \mathrm{g} / \mathrm{ml}$ ethidium bromide at $50 \mathrm{~V} / \mathrm{cm}$ for $2.5 \mathrm{~h}$. DNA was transferred onto $\mathrm{N}+$ nylon membrane (Amersham) for $1 \mathrm{~h}$ in alkali solution (1.5 M NaCl and $0.4 \mathrm{M} \mathrm{NaOH})$ using a vacuum blotting apparatus (Hoefer). Prehybrid- ization treatment of membranes was performed at $65^{\circ} \mathrm{C}$ for $1 \mathrm{~h}$ in $6 \times \mathrm{SSPE}(1 \times \mathrm{SSPE}$ is $0.15 \mathrm{M} \mathrm{NaCl}, 10 \mathrm{mM}$ sodium phosphate, $\mathrm{pH} 7.4$, and $1 \mathrm{mM}$ EDTA), $5 \times$ Denhardt's solution ( $1 \times$ Denhardt's is $0.02 \%$ ficoll, $0.02 \%$ PVP, $0.02 \%$ BSA, $0.5 \%$ SDS), $20 \mu \mathrm{g} / \mathrm{ml}$ sonicated herring sperm DNA. ${ }^{32} \mathrm{P}$-labeled restriction fragments were boiled for $5 \mathrm{~min}$, chilled on ice for $30 \mathrm{sec}$, and then added to the prehybridization solution and hybridized to blots for $16 \mathrm{~h}$ at $>10^{6} \mathrm{cpm} / \mathrm{ml}$. For high stringency analysis, hybridized blots were washed twice at room temperature in $2 \times \mathrm{SSPE}, 0.1 \% \mathrm{SDS}(\mathrm{w} / \mathrm{v})$ for $10 \mathrm{~min}$; once at $65^{\circ} \mathrm{C}$ in $1 \times \mathrm{SSPE}, 0.1 \% \mathrm{SDS}$ for $15 \mathrm{~min}$; and once at $65^{\circ} \mathrm{C}$ in $0.1 \%$ SSPE, $0.1 \%$ SDS for $15 \mathrm{~min}$. Low stringency Southern hybridizations were done for $16 \mathrm{~h}$ at $>10^{6}$ $\mathrm{cpm} / \mathrm{ml}$ at $42^{\circ} \mathrm{C}$ in $2 \times \mathrm{SSPE}$ with $20 \%$ (v/v) formamide included, and blots were washed twice in $2 \times$ SSPE, $0.1 \% \mathrm{SDS}$ at $42^{\circ} \mathrm{C}$ for $30 \mathrm{~min}$. Membranes were wrapped with Handi-wrap and exposed to Hyperfilm MP film (Amersham) with an intensifying screen at $-70^{\circ} \mathrm{C}$. The exposure times varied from 1-3 days.

\section{RNA Gel Blotting and Hybridization Analysis}

Twenty micrograms of total RNA was glyoxaldenatured [Burnett, 1997] at $50^{\circ} \mathrm{C}$ for $1 \mathrm{~h}$ or heat denatured [Pelle and Murphy, 1993] at $75^{\circ} \mathrm{C}$ for $5 \mathrm{~min}$ and size-fractionated on a 1 or $1.4 \%(\mathrm{w} / \mathrm{v})$ agarose gel in 10 $\mathrm{mM}$ phosphate, $\mathrm{pH} 7.0$ or 6.8 , respectively. After electrophoresis, the gel was soaked once in $0.25 \mathrm{~N} \mathrm{HCl}$ for 15 min, neutralized by washing the gel twice in $0.05 \mathrm{~N}$ $\mathrm{NaOH}$, each for $15 \mathrm{~min}$. RNA was transferred to positively charged nylon membrane Hybond $\mathrm{N}^{+}$(Amersham) by capillarity in $0.05 \mathrm{~N} \mathrm{NaOH}$ for $2.5-3$ hours. After a brief rinse with $2 \times$ SSPE, RNA was immobilized onto the membrane with a UV crosslinking oven (Hoefer, San Francisco, CA). Membranes were hybridized with DNA probes as described above for DNA gel blot analysis. The blots were exposed to X-ray films for 3 days to a week. RNA size was estimated from its relative mobility compared to known RNA standards (Bethesda Research Laboratories, MD). Equal loading of RNA samples was ensured either by spectrophotometric determination of RNA concentration in samples, or ethidium bromide staining of the gel, or hybridization of the blot to an $18 \mathrm{~S}$ rDNA probe.

Screening cDNA Libraries A B73 maize library kindly provided by Dr. Alice Barkan was used to isolate ZMM1-4. The libraries were screened using the protocol recommended by the manufacturer (Stratagene, La Jolla, CA) .

\section{RACE PCR}

To obtain full-length myosin cDNA clones, a modified RACE protocol [Frohman et al., 1988] was per- 
formed with the 5' RACE system (BRL, Bethesda, MD) according to the manufacturer's manual. Total RNA (5 $\mu \mathrm{g})$ from shoots was reverse transcribed with SuperScript $^{\mathrm{TM}}$ II reverse transcriptase for $50 \mathrm{~min}$ at $42^{\circ}$ or $50^{\circ} \mathrm{C}$. The reverse transcription reaction was primed using 10 pmol of ZMM1-specific primer 1 (5'-TGCACCCTTGTACTGTTCCA-3'). RNA was degraded by RNase. Unincorporated nucleotides, excess primers and RNA residues were removed using Microcon 100 filters (Amicon, Beverly, MA). cDNA was tailed with dC using terminal deoxyribonucleotide transferase. dC-tailed cDNA was amplified with the ZMM1-specific primer 2 (5'-GTGGCAATCTTTGAAATGGA-3') and abridged anchor primer (5'-GGCCACGCGTCGACTAGTACGGGIIGGGIIGGGIIG-3'). 1/1000 of the first amplification product was used for nested amplification with ZMM1specific primer 3 (5' - TCATAGCGGGTAGCAAGATT$\left.3^{\prime}\right)$ and primer AUAP (5'-GGCCACGCGTCGACTAGTAC). PCR was performed with eLONGase (BRL). The amplification program included an initial step at $94^{\circ} \mathrm{C}$ for $5 \mathrm{~min}, 35$ cycles of $1 \mathrm{~min}$ at $94^{\circ} \mathrm{C}, 2 \mathrm{~min}$ at $55^{\circ} \mathrm{C}$, and 2 min at $72^{\circ} \mathrm{C}$, and a final step at $72^{\circ} \mathrm{C}$ for $5 \mathrm{~min}$. PCR products were fractionated on a $2 \%(\mathrm{w} / \mathrm{v})$ agarose gel (Promega, Madison, WI) and each band of expected size was isolated using GeneClean II (Bio101) as described above. Amplified products were cloned into pGEM-T vector (Promega). Nucleotide sequences of three positive clones were determined to avoid possible PCR errors.

\section{Nucleotide Sequencing and Analysis}

DNA sequencing was determined by the chain termination method [Sanger et al., 1977] using the Thermosequenase radiolabeled terminator cycle sequencing kit (Amersham). All sequences were verified on both strands. The sequence near poly (A) tails at $3^{\prime}$-ends was obtained using anchored oligo-dT primers $\left(5^{\prime}-\right.$ TTTTTTTTTTTTTTTVN-3', $\mathrm{V}=\mathrm{G}$ or $\mathrm{A}$ and $\mathrm{N}=\mathrm{G}$ or A or C). The phylogenetic analysis was conducted with PAUP, version 3.1 [Swofford, 1990]. To define the head/ tail junction of the myosin molecule glutamate ${ }^{733}$ was used as the final head residue following the criterion of [Mooseker and Cheney, 1995].

\section{Subcellular Fractionation by Differential Centrifugation}

Separation of subcellular constituents by differential centrifugation was carried out according to the methods of Bonner [1976] and Rickwood et al. [1994). Twenty grams of corn young roots were homogenized in $80 \mathrm{ml}$ of homogenization buffer $(50 \mathrm{mM}$ Tris- $\mathrm{HCl}, \mathrm{pH}$ 8.0, $250 \mathrm{mM}$ sucrose, $5 \mathrm{mM}$ EDTANa $2,1 \mathrm{mM} \mathrm{MgCl}_{2}, 1$ $\mathrm{mM} \mathrm{CaCl}, 10 \mathrm{mM} \beta$-mercaptoethanol, and $1 \mathrm{mM}$ PMSF) at a high speed for $15 \mathrm{sec}$ under Oster Commercial Bar Mixer. The homogenization solution was filtered through Miracloth (Calbiochem Corporation, La Jolla, CA 92037), and transferred into two centrifuge tubes. The homogenization solution was centrifuged at $500 \mathrm{~g}$ at $5^{\circ} \mathrm{C}$ for 20 min in a Beckman Avanti ${ }^{\mathrm{TM}} \mathrm{J}-30 \mathrm{I}$ centrifuge. The pellet (i.e., subcellular fraction 1, the nuclear/cell wall fraction) was resuspended in PHEM plus $10 \mathrm{mM}$ PMSF and the protein concentration was determined. SDS-PAGE sample buffer was added to the remainder and stored at $4^{\circ} \mathrm{C}$. The supernatant from the first centrifugation was recentrifuged at $2,000 \mathrm{~g}$ at $5^{\circ} \mathrm{C}$ for $20 \mathrm{~min}$. The pellet (i.e., subcellular fraction 2 , the plastid fraction) was treated as for subcellular fraction 1 . The supernatant was recentrifuged at $10,000 \mathrm{~g}$ at $5^{\circ} \mathrm{C}$ for $20 \mathrm{~min}$. The pellet (i.e., subcellular fraction 3 , mitochondrial fraction including lysosomes and peroxisomes) was treated as for subcellular fraction 1 . The supernatant was recentrifuged at $105,000 \mathrm{~g}$ at $5^{\circ} \mathrm{C}$ for $2 \mathrm{~h}$. The pellet (i.e., subcellular fraction 4 including vesicles from the plasma membrane, endoplasmic reticulum, and Golgi apparatus) was treated as for subcellular fraction 1 . The pellets were incubated with propidium iodide to stain DNA. Confocal microscopy indicated that pellet no. 1 had DNA-containing organelles that were generally round and 5.5-19.5 $\mu \mathrm{m}$ in diameter (nuclei). Pellet no. 2 had DNA-containing organelles that were elongated and $2.0-3.5 \mu \mathrm{m}$ in length (chloroplasts). Pellet no. 3 had slightly elongated to spherical DNA-containing organelles that were 2.0 $1.0 \mu \mathrm{m}$ in length (mitochondria). Pellet no. 4 had very few DNA-containing organelles.

Design and Purification of the M11L1 (Myosin Class XI, Loop 1) Antibody. A small hydrophilic area of the myosin head was chosen for use as an antigen. The deduced peptide sequence EGRTVEQQVLESNPV is conserved in myosin XI, but is not present in myosin VIII. The peptide was synthesized by Genemed Synthesis Inc. (San Francisco, CA) with a amino-terminal cysteine to aid in ligand binding and affinity purification. A SulfoLink kit (Pierce Inc., Rockford, IL) was used for affinity purification of the antibody.

\section{Western Blotting}

Each of the subcellular fractions described above were thawed and recentrifuged at $12,000 \mathrm{~g}$ at $4^{\circ}$ for 15 min to remove insoluble debris. Twenty micrograms of total protein were loaded onto each lane for SDS-PAGE. The protein patterns on the $9 \%$ gels were blotted onto nitrocellulose membrane at $24 \mathrm{~V}$ for $1 \mathrm{~h}$ under MINIGENIE Blotter (Ideal Scientific Company, Minneapolis, $\mathrm{MN}$ ). The membrane was blocked with PBS ( $\mathrm{pH} 7.2$ ), $3 \%$ BSA and $0.25 \%$ gelatin for $2 \mathrm{~h}$. The membrane was incubated for $2 \mathrm{~h}$ with the purified myosin antibody (1:100). After washing, the membrane was incubated for $2 \mathrm{~h}$ with secondary antibody, alkaline phosphatase-conjugated goat anti-rabbit $\operatorname{IgG}(\mathrm{H}+\mathrm{L})$ (1:300). After wash- 
ing again, the membrane was developed in alkaline phosphatase substrate solution until purple reaction product appeared on the membrane.

\section{Immunolocalization of Myosin}

Sections were made from the primary root of corn. Root tips were fixed in $4 \%$ formaldehyde in $1 \times$ PHEM (60 mM PIPES, $25 \mathrm{mM}$ HEPES, $10 \mathrm{mM}$ EGTA, $4 \mathrm{mM}$ $\mathrm{MgCl}_{2}, \mathrm{pH}$ 6.9) solution at room temperature for $4 \mathrm{~h}$ and stored at $4^{\circ} \mathrm{C}$. Root tips were sectioned at $80 \mu \mathrm{m}$ with a Vibratome (Ted Pella, Inc., Redding, CA). Sections of root tips or subcellular fractions 1,2,3, and 4 were dried on slides coated with $0.1 \%$ poly-L-lysine solution. Sections were digested for 20 min with $2 \%$ driselase and $1 \%$ pectinase in PBS, washed with $1 \times$ PHEM, permeabilized with $1 \%$ Triton X-100 in $1 \times$ PHEM, and washed with $1 \times$ PHEM. Staining sections with the whole serum at concentrations of 1:1,000 resulted in binding to many portions of the cell including nuclei and cell walls. Therefore, for immunostaining, sections and subcellular fractions were incubated for $2 \mathrm{~h}$ with affinity purified antibody M11L1 (1:5), washed with PBS, and incubated with FITC-goat anti-rabbit $\operatorname{IgG}(\mathrm{H}+\mathrm{L})$ (1:50). After washing with PBS, the sections were labeled with 5 $\mu \mathrm{g} / \mathrm{ml}$ propidium iodide, washed with PBS, mounted with Mowiol $/ p$-phenylenediamine (9:1), and stored at $4^{\circ} \mathrm{C}$ overnight. The sections were examined with a BioRad MRC1024ES confocal laser-scanning microscope system equipped with an argon-krypton laser. For controls, tissues were incubated either with no antibodies (which showed that very little autofluorescence was present), secondary antibody only (which showed that the non-specific binding of antibodies to fixed tissues was quite low), or with antitubulin (which showed that the overall level of tissue preservation was acceptable).

\section{RESULTS}

\section{Production of Myosin PCR Probes for Library Screening}

All four combinations of degenerate primers (i.e., $\mathrm{EB}, \mathrm{ZB}, \mathrm{ED}$, and $\mathrm{ZD}$ ) generated PCR products of the expected size with minimal nonspecific amplification using cDNA synthesized from total RNA from the maize variety "Merit" (data not shown). At least twelve clones derived from amplification products from each pair of primers were randomly selected and sequenced. The typical sizes of RT-PCR products from each pair of primers were $180 \mathrm{bp}$ for $\mathrm{EB}, 312 \mathrm{bp}$ for $\mathrm{ZB}, 753 \mathrm{bp}$ for $\mathrm{ED}$, and $912 \mathrm{bp}$ for ZD. Five different PCR clones were selected and designated as probes EB09, ZB30, ZB35, ED44, and ZD3.

\section{Isolation of Four Distinct Z. mays Myosin (ZMM) Sequences}

The cDNA library was screened at low stringency with the PCR-generated probes. Twenty-two positive clones were purified and partially sequenced from both ends to verify their identity as myosin clones. Four types of myosin were detected. The longest clone of each type was selected and designated as ZMM1 (GenBank accession no. AF104924), ZMM2 (GenBank accession no. AF147739), ZMM3 (GenBank accession no. AF147738), and ZMM4), respectively. The sequences of ZMM1 and ZMM4 were identical in the $5^{\prime}$-region but differed in the $3^{\prime}$-UTR region for a length of at least 250 base pairs. Therefore, ZMM1 and ZMM4 may be splicing isoforms although the full ZMM4 sequence will be required to confirm this.

Clones ZMM1, ZMM2, and ZMM3 were selected for further study. All these clones appeared to be truncated at their $5^{\prime}$-end because (1) no putative translation initiation codons were present in the $\mathrm{N}$-terminal region of their longest open reading frame, and (2) the size of the cDNA clones was 500-700 bp smaller than the size of their respective mRNAs as determined by Northern analysis. To clone the missing 5 '-end of these clones, RACE PCR was performed. A PCR product of approximately 750 bp was successfully obtained for ZMM1. The PCR product was cloned and three independent clones were selected for sequencing. All of them had identical sequences and overlapped the $5^{\prime}$-end of the ZMM1 cDNA clone by $222 \mathrm{bp}$. The combined length (minus duplicated

Fig. 1. A: Deduced amino acid sequence of ZMM1. Some conserved regions have been emphasized. The initial portion of the protein has little if any sequence similarity with non-plant myosins, but downstream of residue 63 a region of conserved, albeit discontinuous, residues occurs (VDDMTRLSYLHEPGVLQNLATRYELNEIYTYTGSILIAVNP). The GESGAGKTET sequence (residues 156165 ) is the P-loop site involved in ATP binding and was used for primer Z. The YIRCVKPN sequence (residues 627-634) is an actinbinding site. Glutamate residue 733 (E) is the final head residue according to the convention of Mooseker and Cheney [1995]. Residues 737-880 (RAAR .... KLKMA) comprise a region of 6 IQ motif consensus sequences (see Fig. 2B). The IQ motifs overlap with the $\mathrm{N}$-terminal portion of a putative coiled-coil region (residues 870 through 1051, ARRELRK ....... . VLRQQ). Near the middle of the coiled-coil region the sequence APPVIKETPV (Residues 958-967) contains 3 helix-breaking prolines. Residues 896-914 (KRVE ..... LRTD) comprise a putative bipartite nuclear localization signal that is located within the putative coiled-coil region. Residues 1499-1521 (SKSM. . . .ENSG) comprise the longest unbroken tail sequence that is not shared with the other ZMMs. B: IQ motif sequences. Six IQ motifs present in tandem immediately downstream of the head-tail junction of ZMM1 (see Fig. 2A). C: Amphipathic heptad repeats (abcdefg) $)_{n}$ in the tail of ZMM1. Residues 958-967 are excluded because they do not comprise a sequence of amphipathic residues and because of several proline residues. 
1A:

MGTPVGIIVGSHVWVEDPNLAWIDGEVISIKNNEVHVQTSNGKKVTTDRSKVFPKDMEAP 60 PGGVDDMTRLSYLHEPGVLONLATRYELNEIYTYTGSILIAVNPFQRLPHLYDTHMMEQY 120 KGADFGELSPHDFAIADVAYRAMDNEGKSNSILVSGESGAGKTETTKMLMRYLAHLGGRS 180 GVEGRTVEQQVLESNPVLEAFGNAKTVRNNNSSRFGKFVEIQFDKTGRISGAAIRTYLLE 240 RSRVCQINSPERNYHCFYFLCAAPPEYTQRYKLSDPRSFHYLNQSSCIEVDGINDAEEYL 300 ATRRAMDIVGINEEEQEGIFRVVAAVLHLGNINFAKGTEIDSSVIKDDKSRFHLNIAAEL 360 LKCDCQNLEKALITRVIVTPEEVITRTLDPASAVASRDALAKITYSRLFDWIVEKINVSI 420 GQDPNSKQLIGVLDIYGFESFKVNSFEQLCINYTNEKLQQHFNQHVFKMEQEEYTREEIN 480 WSYIEFVDNQDVLDLIEKKPGGLIALLDEACMFPRSTHETFAQKLYTTFKNNKRFAKPKL 540 SRTDFTVVHYAGDVTYQADYFLDKNKDYVVAEHQDLLNASSCLFVAGLFPPLPQETAKSS 600 KFSSIGSRFKLQLQSLMETLSSTEPHYIRCVKPNNLLKPAIFENTNVIQQLRCGGVLEAI 660 RISCAGYPTRKTFYEFVNRFGVLAPEVLEGSNDDKIACQKILEKMGLENYQIGKTKVFLR 720 AGQMADLDARRAEVLGRAARIIQRQIRTYIARKQFAELKRSATQLQSFVRGTLARKL YEC 780 MRQEAAAVKIQKNMRRHKARESYLQLQAAAITLQTGLRAMSARKEFRFRKETKAAVHIQA 840 QWRRHRAYSHYKNLQGAALTIQCAWRQRLARRELRKLKMAARETGALKEAKDKLEKRVEE 900 LTWRLGLEKRLRTDLEEAKAOEIAKLOETLHDMOLOVEESKAMVVKEREAARKAIEEAPP 960 VIKETPVLVEDTEKINSLTTEVEOLKALLLTEROATEAAKREHAESELRNEELIKKFESA 1020 EKKIEOLOETVHRLEEKATNMESENKVLROQAVAISPTSKSLAAYPKSPFQLKTPENGNA 1080 LNGEVKSSPDITPILPNPKELEAEEKPQKSLNEKQQENQDLLIKCVSQDLGFSSGKPIAA 1140 CLIYRCLLHWRSFEVERTGVFDRIIQTIGSAIESQDNNDKLAYWLSNSSTLLLLLQRTLK 1200 TTGAAGFTPQRRRSSAASFGRVFSGMRASPQSAGRAFMGSRLIGGLGDLRQVEAKYPALL 1260 FKQQLTAFLEKIYGMIRDNLKKEISPLLGLCIQAPRTSRASLIKGSRSQANALAQQTLIA 1320 HWQSIVKILTNYLNVLKANYVPSVLISKVFTQIFSFINVQLFNSLLLRRECCSFSNGEYV 1380 KAGLAELEQWCIYATEEYAGSSWEELKHIRQAVGFLVIHQKPKKTLKEITNDLCPVLSIQ 1440 QLYRISTMYWDDKYGTHTVSSDVISSMRVMMTEDSNNAVSSSFLLDDDSSIPFSVDDISK 1500 SMTEIEVTDVDMPPLIRENSGFTFLHQRKD 1530

1B: $\begin{array}{llllll}\text { IQ1 } & 737 & \text { RAARI } & \text { IQRQIRTYIARKQF } & \text { AELK } & 759 \\ \text { IQ2 } & 764 & \text { RSATQ } & \text { LQSFVRGTLARKLY } & \text { ECMRQE } & 784 \\ \text { IQ3 } & 785 & \text { AAAVK } & \text { IQKNMRRHKARESY } & \text { LQLQ } & 807 \\ \text { IQ4 } & 812 & \text { AAAIT } & \text { LQTGLRAMSARKEF } & \text { RFRKET } & 832 \\ \text { IQ5 } & 833 & \text { KAAVH } & \text { IQAQWRRHRAYSHY } & \text { KNLQ } & 855 \\ \text { IQ6 } & 856 & \text { GAALT } & \text { IQCAWRQRLARREL } & \text { RKLKMA } & 880 \\ \text { Consensus } & \text {. AA. . } & \text { Iq...R...Ark.Y . } & 1 \ldots & \end{array}$

1C:

$\begin{array}{lccccc}870 & \begin{array}{l}\text { ARRELRK LKMAARE TGALKEA KDKLEKR VEELTWR LGLEKRL RTDLEE AKAQE } \\ \text { abcdefg abcdefg abcdefg abcdefg abcdefg abcdefg abcdef cdefg }\end{array} \\ 923 & \begin{array}{l}\text { IAKLQET LHDMQLQ VEESKAM VVKEREA ARKAIEE } 957 \\ \text { abcdefg abcdefg abcdefg abcdefg abcdefg }\end{array} & \ldots 58 \text { APPVIKETPV } & 967 \\ 968 & \begin{array}{l}\text { LVEDTEK INSLTTE VEQLKAL LLTERQA TEAAKRE HAESELR NEELIKK } \\ \text { abcdefg abcdefg abcdefg abcdefg abcdefg abcdefg abcdefg }\end{array} & 1017 \\ 1018 & \begin{array}{l}\text { FESAEKK IEQLQET VHRLEEK ATNMESE NKVLRQQ } \\ \text { abcdefg abcdefg abcdefg abcdefg abcdefg }\end{array} & & \\ \end{array}$ 
overlapping regions) of this RACE PCR product and the original ZMM1 cDNA was approximately $5.4 \mathrm{~kb}$, agreeing with the mRNA size as detected by Northern analysis.

\section{Sequence analysis of ZMM1, ZMM2, and ZMM3}

The full-length ZMM 1 was 5,378 bp long and composed of a 374 bp 5'-UTR, a 4,593-bp coding sequence, and a 411-bp 3'-UTR. The predicted protein consisted of 1,530 amino acids, with a molecular weight of $173.5 \mathrm{kDa}$ and a $\mathrm{pI}$ of 8.37 (Fig. 1). The initiator methionine was determined by three criteria: (1) The flanking sequences 10 residues up- and downstream of the putative initiator codon had $50 \%$ sequence similarity to the monocotyledon consensus context sequences flanking initiator codons [Joshi et al., 1997]; (2) No methionine was present upstream of the putative initiator in any of three possible reading frames; (3). Two inframe stop codons were found upstream of the initiator methionine.

A search of GenBank with the NCBI BLAST program [Altschul et al., 1990] revealed that the 5'-UTR and 3'-UTR of ZMM1 did not share significant homology with other sequences, but the translated portion of ZMM1 was very similar to myosins from the dicotyledons Helianthus annuus (Hamy5, 74\% amino acid identity, $80 \%$ nucleic acid identity) and Arabidopsis (MYA1, $68 \%$ amino acid identity, $79 \%$ nucleotide identity). The amino-terminal half of ZMM1 contained the highly conserved ATP-binding sequence (GESGAGKT) and actin binding sequence (RCIKPN) as well as other highly conserved sequences found in almost all myosins (Fig. 1A). The head-tail junction was defined by glutamate ${ }^{733}$ that was a few residues upstream of six repeats of $\sim 23$ amino acid residues with a consensus of (I/ L)QXXXRXXXAR (where $X$ is any amino acid), known as IQ motifs (Fig. 1B). IQ motifs have been shown to serve as binding sites for calmodulin [Espreafico et al., 1992; Halsall and Hammer, 1990] or myosin light chains [Rayment et al., 1993] in animal myosins. A portion of the sixth IQ motif overlaps with a downstream region containing 200 amino acids (Fig. 1C) that have the potential to form a-helical coiled coils [Lupas et al., 1991], implying that ZMM1 may dimerize. The distalmost domain of ZMM1 (including the C-terminus) was of unknown function. Because of the existence of an initiator codon, a 3'-UTR, and the extensive sequence similarities between ZMM1 and other myosins, we concluded that it was a full-length synthetic myosin gene from maize.

The nucleotide sequences (including portions of the $3^{\prime}$-UTR) and predicted amino acid sequences of two other maize myosin cDNA clones, ZMM2 and ZMM3, were determined except for some missing residues near the N-terminus. ZMM2 was 4,313 bp long. It consisted of an open reading frame of 4,059 bp and a 3' UTR of $254 \mathrm{bp}$. The open reading frame encoded a polypeptide of 1,352 amino acids with a predicted molecular weight of $153.7 \mathrm{kDa}$, an isoelectric point of 8.46 , six IQ motifs immediately downstream of the head-tail junction, and amphipathic residues in the proximal tail region with the potential to form a-helical coiled coils. The tail length of ZMM2 was about the same as that of ZMM1.

ZMM3 had a length of 3,552 bases, an open reading frame that encoded 1,099 amino acids, and a 3' UTR of $252 \mathrm{bp}$. The sequenced head region of ZMM3, and here it must be realized that this clone was incomplete at the $5^{\prime}$ end, was longer than that of the complete myosin ZMM1 by at least 37 amino acids. However, the tail of ZMM3 differed from both ZMM1 and ZMM2 in that it was approximately 470 amino acids shorter, had only three IQ motifs, and a relatively short stretch of putative coiled coil comprised of only 6 amphipathic heptad repeats.

Comparison of the ZMM amino acid sequences (Fig. 2) shows that the ZMM3 tail region has fewer IQ motifs, a shorter putative coil-forming region, and a shorter globular C-terminal region than either ZMM1 or ZMM2. The head region of ZMM3 is also larger than that of ZMM1. In contrast, sequence length appears to have been conserved between the ATP-binding GESGAGKT sequence and the IQ motifs of ZMM1 and ZMM3. This similarity is also likely to be true for ZMM2 because the C-terminal residues of the GESGAGKT sequence seem to be present at the $\mathrm{N}$-terminus of this clone.

\section{Comparison of Clones}

When the amino acid sequences of ZMM1, ZMM2, and ZMM3 were compared using the NCBI BLAST program significant similarity was found (Table I). ZMM1 and ZMM2 resembled each other more than they did ZMM3. This was true regardless of whether the heads, tails, or entire sequences were compared. In all cases the ZMM heads had more similarity to each other than did the tails. At the nucleotide level, the tail sequence of ZMM3 did not have significant similarity to ZMM1 and ZMM2. This observation is reminiscent of data from animal myosins that have IQ motifs and coiledcoil regions, but can have a low degree of sequence similarity to each other [McLachlan and Karn, 1982]. Two conclusions are clear from these data. One, ZMM3 has diverged considerably from ZMM1 and ZMM2 and, two, the rate of sequence divergence has been relatively rapid in the tail region compared to the head region.

When the amino acid tail sequences of ZMM1 and ZMM2 are aligned with the Multalin program [Corpet, 1988] (version 5.3.3:4; data not shown), there was only one substantial region, a stretch of 23 residues starting 10 
Fig. 2. ZMM amino acid sequence diagrams. The rectangular box representing each clone has been drawn to scale and represents the length of a deduced amino acid sequence (for ZMM2 and 3 the length of an uncloned open reading frame has been included as an approximation). The numbers above each box represent the amino acid residue boundaries of some important sequences. IQ motifs are represented as checkered ellipses (6 in ZMM1 and ZMM2, 4 in ZMM3). Putative coilforming regions are represented as zigzag lines. For ZMM1 and ZMM3, the number of amino acids between the ATP binding motif (GESGAGKT sequence) and the IQ motif is quite similar (i.e., 571 and 575, respectively). For ZMM2, the number 573 is probably a good approximation of the connector region length because the amino-terminal residue of this clone is apparently the last residue in the ATP binding site. The tail of ZMM3 (i.e., the segment between the IQ motifs and the C-terminus) is relatively short.
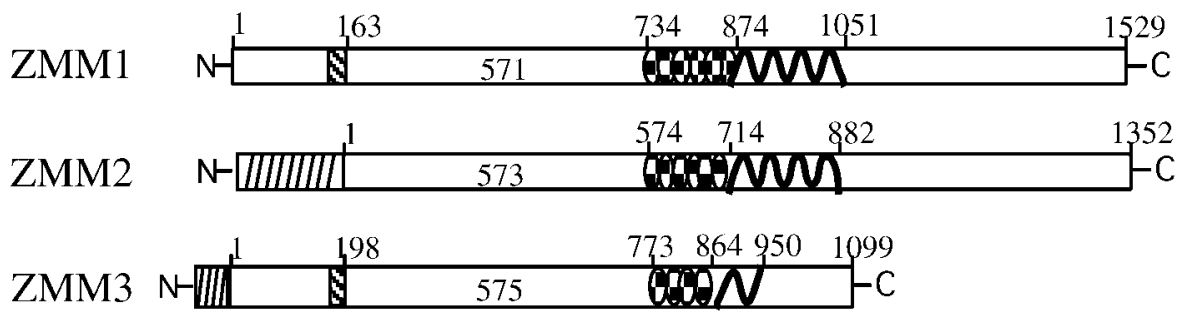

IIII uncloned ORF ATP-binding motif $O$ IQ motif $\quad \Lambda$ Coils residues upstream of the $\mathrm{C}$ terminus, in which sequence identity was totally absent (Fig. 2A). This region is predominantly composed of hydrophilic residues and presumably would be an excellent ZMM-specific epitope region. When this 23-residue region was analyzed with BLAST, significant similarity was only found with two myosin-like Arabadopsis genomic sequences, and the cDNA sequences for Hamy5 (Helianthus myosin) and MYA1 (Arabadopis myosin). In contrast, when the analogous ZMM2 region (i.e., LSDHLLICCIFFGSFLPHVPF) was analyzed with BLAST, no sequence identity with any other myosin was detected.

TABLE I. Sequence Similarity Among Clones*

\begin{tabular}{lllll}
\hline & ZMM2 & ZMM3 & PCRZB35 & PCREB8 \\
\hline ZMM1 & & & & \\
$\quad$ All & $75(76)$ & $59(78)$ & & \\
Head only & $86(76)$ & $61(78)$ & $91(79)$ & $94(84)$ \\
$\quad$ Tail only & $71(76)$ & $51(\mathrm{NSS})$ & & \\
ZMM2 & & & & \\
$\quad$ All & & $60(78)$ & & $93(82)$ \\
$\quad$ Head only & & $63(78)$ & $93(84)$ & \\
$\quad$ Tail only & & $48($ NSS $)$ & & $79(82)$ \\
ZMM3 & & $78(82)$ & \\
$\quad$ Head only & & & & $96(82)$ \\
PCRZB35 & & & & \\
$\quad$ Head only & & & & \\
\hline
\end{tabular}

*Percentage of amino acid and nucleotide (parenthesis) sequence similarity of five maize myosin sequences. For each clone, the similarity of either all or a portion of its sequence to the corresponding portion (if such exists) of the other clones is indicated. NSS indicates no significant similarity.
Comparison of the three $\mathrm{ZMM}$ cDNA sequences with the PCR clones (i.e., EB8, ZB30, ZB35, ED44, and ZD3) used as probes revealed that ZMM1, ZMM2, and ZMM3 had sequences identical to PCR clones ZD3, ZB30, and ED44, respectively (data not shown). EB8 and ZB35 appeared to represent unique myosins. The significant differences between all of the clones analyzed in Table I indicates that at least five myosin genes exist in maize.

\section{Southern Blot Analysis}

Low-stringency hybridization Southern analysis of genomic DNA from maize inbred line B73 was performed using clone ZB35 as a probe to assess the complexity of the myosin gene family in maize. PCR clone ZB35 was 312 base pairs long and did not have the internal restriction sites used here for digesting genomic DNA (data not shown). Depending on the type of restriction enzyme used for digestion, as many as six bands were visible (Fig. 3A, EcoRI lane). Our analysis of GenBank sequences indicates that Arabadopis myosin ATM2 (GenBank accession no. AB10695) has three introns in the $\mathrm{ZB}$ region. If the same were true for maize myosins, then the possibility exists that a single gene could give rise to two or more bands on the Southern blots. Given that EcoR I is a "six-cutter" restriction enzyme, the probability that an EcoR I site is present in the genomic EB region is small, but analysis of genomic sequences is required to clarify this situation.

For a more specific analysis, fragments derived from head and tail regions of ZMM cDNA clones were 

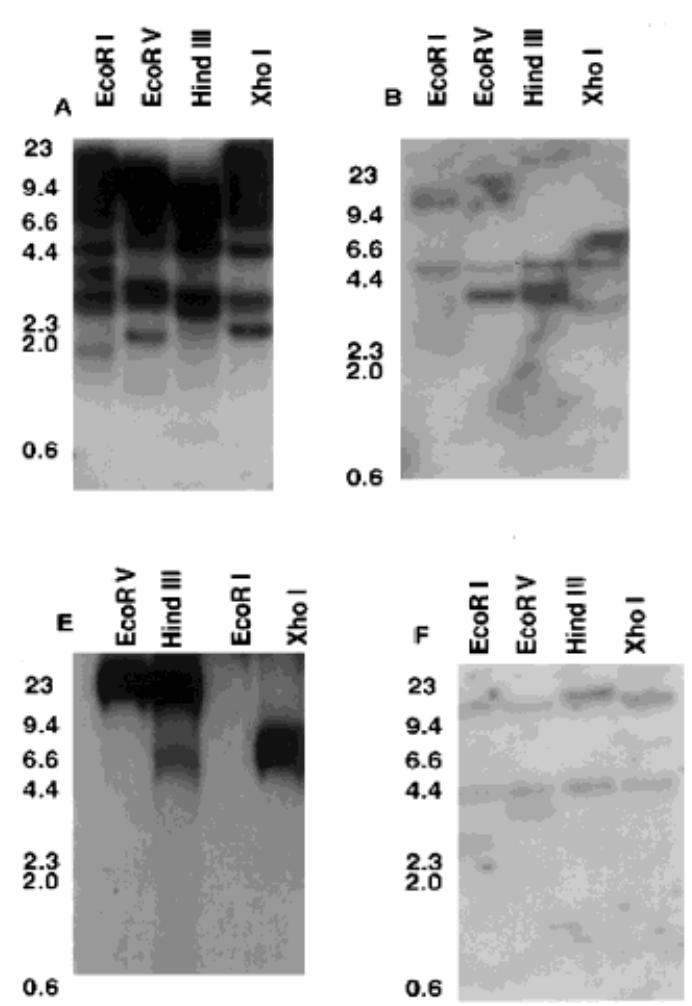

Fig. 3. Southern analysis of the maize myosin gene family. Several probes were used. PCR fragment ZB35 was hybridized with genomic DNA at low stringency (A). At least 6-7 bands are evident in the EcoR1 lane. Other blots were hybridized under high stringency conditions with probes either made from the head (B) or the tail (C) of

used as probes. High stringency Southern hybridization greatly decreased the number of bands observed in each lane. For analysis of ZMM1, two EcoR I fragments, 2.0 and $1.0 \mathrm{~kb}$, corresponding to the head and tail respectively, were used as probes. The ZMM1 head fragment hybridized with several bands (Fig. 3B). The bands in the EcoR V and Hind III lanes were due to internal restriction sites within ZMM1. When an EcoR I tail fragment of ZMM1 containing residues 3555-4551 was used as a probe only a single signal was visible in each restriction digest (Fig. 3C), suggesting that this probe hybridized with only one gene in each digest. This probe was later used to detect ZMM1 transcripts on Northern blots.

Digestion of ZMM2 with EcoR V yielded two fragments, one 1.4 and another $2.2 \mathrm{~kb}$. The $1.4-\mathrm{kb}$ fragment was a portion of the head and, when used as a probe, reacted with one to two genomic fragments in separate Xho I, Hind III, and EcoR V digests (Fig. 3D). The 2.2-kb EcoR V fragment from the tail of ZMM2 labeled a single major band in three of the restriction digests but not in the EcoR I-treated digest (Fig. 3E). This fragment was later used for the detection of ZMM2 mRNA on Northern blots. The absence of signals in the
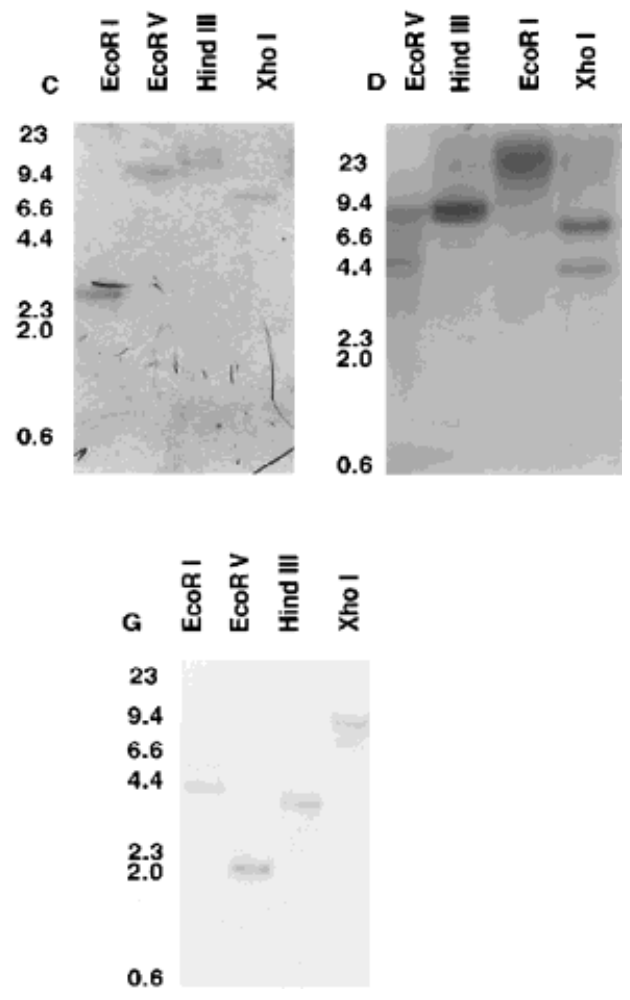

ZMM1, ZMM2 (D, head; E, tail) and ZMM3 (F, head; G, tail). The number of bands/lane is much lower in the high stringency blots. Head probes from ZMM1 and ZMM3 label more bands on each blot than do the tail probes from the same clones. In almost all cases, different size bands are labeled by the head and tail probes from one clone.

EcoR I lane for both the 1.4- and 2.2-kb probes was not likely to be due to failure of restriction digestion or degradation because these same blots gave rise to sharp bands when probed with other DNA fragments. Instead, a lack of EcoR I sites may have prevented genomic DNA from entering the gel.

When ZMM3 was digested with EcoR I, a 1.7 and a $1.4 \mathrm{~kb}$ fragment resulted. The former contained most of the head sequence, while the latter contained a small portion of head and the entire tail. Two or three bands of approximately equal intensity were present in each lane when the 1.7-kb head fragment was used as a probe (Fig. 3 F). While the multiple signals in the EcoR V, Hind III, and Xho I lanes can be explained by the existence of internal restriction sites, the presence of multiple bands in the EcoR I lane is problematic. In contrast, the tail fragment of ZMM3 produced single bands for EcoR I, Hind III, and Xho I (Fig. 3G). Therefore, the 1.4-kb EcoR I tail fragment was more appropriate for Northern analysis than the 1.7-kb head fragment. A general observation for all of the ZMM clones was that the tail fragment, when used as a probe, hybridized with fewer bands than the head fragment. In all likelihood, this is a 
Fig. 4. Northern analysis of total RNA. Probes were from the tail of ZMM1 (A), ZMM2 (B), and ZMM3 (C, D). Total RNA was isolated from root (RT), stem (ST), leaf (LF), coleoptile (CO), seed kernel (KL), pollen (PL), and silk (SK). The blots were reprobed with $18 \mathrm{~S}$ DNA probes (bottom) to confirm equal loading.

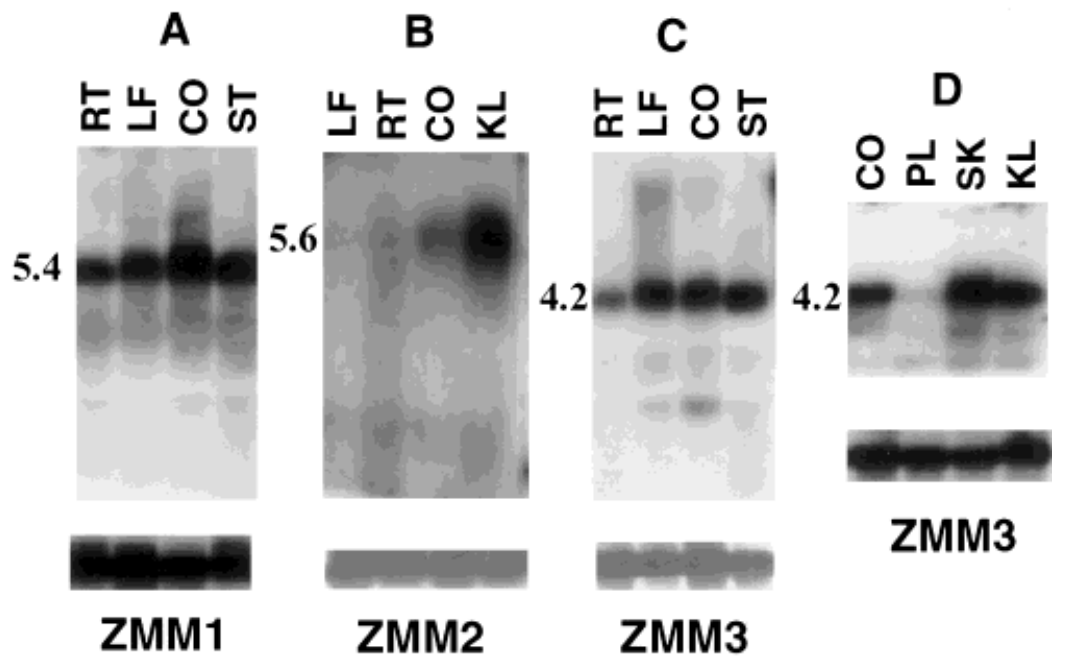

reflection of the low sequence similarity among the ZMM tails (Table I).

\section{Northern Blot Analysis}

The sizes and expression patterns of maize myosin transcripts were determined by Northern blot analysis using total RNA from the Merit cultivar, and fresh kernels, pollen, and silks from ears purchased locally. Each of the ZMM clones showed a unique pattern of expression. The EcoR I $1.0 \mathrm{~kb}$ tail fragment of ZMM1 hybridized with a single mRNA band with an estimated size of $5.4 \mathrm{~kb}$ (Fig. 4A). ZMM1 was expressed abundantly in 4 tissues (root, leaf, coleoptile, and stem) with the highest level found in coleoptile and the lowest in root. The ZMM2 2.2-kb EcoR V tail fragment hybridized with a band of mRNA that was roughly the same size as that detected with the ZMM1 EcoR I fragment (Fig. 4B). ZMM2 transcripts were undetectable in leaf and root, present at a moderate level in coleoptile, and abundant in immature seed. The 1.4-kb EcoR I ZMM3 tail fragment hybridized with an mRNA band of approximately $4.2 \mathrm{~kb}$ (Fig. 4C). The transcript level in the ZMM3 major band was approximately equal in leaf and coleoptile, but was relatively low in root. Expression of ZMM3 was detectable in silk and seed, but very faint in pollen (Fig. 4D).

\section{Alignment of ZMM1, ZMM2, and ZMM3 Head Regions}

Mechanochemical proteins such as myosin interact with other proteins and membranes. These interactions can be affected by both the sequence and the length of domains within a protein. Using the Multalin program, the amino acid sequences of the ZMM clones were aligned with each other to detect regions of sequence similarity and those in which conceptual gaps occurred. The two class XI myosins aligned with each other with- out the need for any gaps in their head regions, but their alignment with ZMM3 required gaps at 13 locations (Fig. 5). Thus, the alignment of these 13 head regions appears to be a reliable mini-diagnostic test for designation of the ZMM clones as either class VIII or XI myosins in maize.

\section{Phylogenetic Analysis of ZMM Clones}

To achieve a wider understanding of the phylogenetic relationships of maize myosins, we compared the deduced amino acid sequences of the ZMMs with those of myosins from dicotyledons and nonplant species. Most of the twelve higher plant myosin genes in Genbank seemed to lack a small portion of N-terminal sequence, but all of them except for one, Hamy2, have complete tail sequences. For our phylogenetic analysis, the junction of the myosin head and tail was defined by glutamate $^{733}$ of ZMM1, or its equivalent in other myosins, which is located a few residues upstream of the first IQ motif. Using PAUP3.1, myosin sequences of either the head or the tail coding sequences were analyzed separately to construct two rooted trees (Fig. 6A,B). As an outgroup member, myosin MYO2 from yeast (Saccharomyces cerevisiae, GenBank no. P19524) was used.

The trees consistently showed that higher plant myosins segregated into three groups. One group consisted of the class XI myosins ZMM1, Hamy2, Hamy5, and MYA 1. ZMM2, MYA2, and Hamy4, also from class XI, were the second group. MYA3, also a class XI myosin, consistently segregated uniquely. The fourth group was formed by the class VIII myosins ZMM3, ATM1, ATM2, and Hamy3.

Myosin members of the same class consistently segregated together irrespective of whether coding sequences from the head, tail, or entire molecule were used to construct phylogenetic trees. This supports the usefulness of class VIII and XI as taxa. However, the precise 
relationship between the two classes was dependant upon whether the head or the tail regions are used for analysis. Comparison of the head regions resulted in a close relationship of class VIII (including ZMM3) to class I and

$1 \quad 1<---V O-\cdots>1$
1 MGTPVGIIVG SHVWVEDPNL AW.IDGEVIS IKNNEVHVQT SNGKKVTTDR

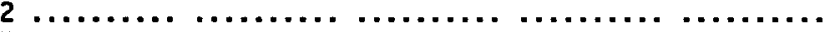
3 DTSSYGAKKK HRVFCQLPNG DWALCTRQLL PLVHESVVKV SEGKVLRLKT

$51 \downarrow<----V 1-\cdots>1$

100 1 SKVFPKDMEA PPGGVDDMTR LSYLHEPGVL QNLATRYELN EIYTYTGSIL 2 ...................................... 3 ECLQPANPEI LDG.VDDLMQ LSYLSEPSVL YNLQYRYSKD MIYTKAGPVL

$101 \downarrow<--V 2-->1$ [<---V3--->!

150

1 IAVWPFORLP HLYDTHMMEQ YKGADFGELS PHDFAIADVA YRAMDNEGKS

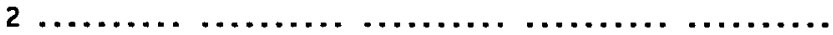
3 VAVNPFKKVS .LYGNEYIDA YRNKSMD..S PHVYAIADAA LCEMKRDEVN

151 $1<-\cdots-.-1-V 4-\cdots>1200$ 1 NSILVSGESG AGKTETTKML MRYLAHLGGR SGVEGRTVEQ QVLESNPVLE 2 ............ ..TESTKMI MRYLAYMGGK AASEGRTVEK QVLQSNPVLE 3 QSIIISGESG AGKTETAKIA MQYLASLGGG SG......IEY EILQTNPILE

251 $1<-\cdots--V 2-\cdots>$

300

1 PERNYHCFYF LCA.APPEYT QRYKLSDPRS FHYLNOSSCI EVDGINDAEE 2 PERNYHCFYM ICA.APPEER ERYKLGDPST FHYLNOSNCI KLEGLDESKE 3 GERSYHIFYQ LCAGAPASLK EKLNLKKVDG YKYLKQSCCY SIAGVDDAQM

$351+<--V 6--->1$

400

1 KSRFHLNIAA ELLKCDCQNL EKALITRVIV TPEEVITRTL DPASAVASRD 2 KSLSHLRTAA ELLMCDEKAL KDSLCQRIIV TRDENIVKTL DPEAAKGSRD 3 EAS....KTVS ELLGCSIEDL NLALSKRHMK VNNENIVQKL TLAQATDIRD

401

$$
1<\cdots-\cdots 7-\ldots>1
$$

450

1 ALAKIIYSRL FDWIVEKINV SIGQDPN.SK QLIGVLDIYG FESFKVNSFE 2 ALAKTVYSRL FDWLVNKINN SIGQDPN.SK CLIGVLDIYG FESFKTNSFE 3 ALAKSVYASL FEWLVEQINK SLSVGKRRTG RSISILDIYG FESFDKNSFE

501

$1<\cdots-\cdots 8 \cdots+\cdots 550$ 2 KKPGGIIALL DEACMLPRST HETFAQKLYQ TYKNHKRFAK PKLSRSDFTI 3 KKPLGLLSLL DEESTFPNAT DLTFANKLKQ HLDSNSCFRG ER. . GKAFAV

551 $1<---V 9-\ldots>1 \quad 600$

1 VHYAGDVTYQ ADYFLDKNKD YVVAEHQDLL N...........ASSCLFVAG

2 CHYAGDVTYO TELFLDKNKD YVVAEHQALL S...........ASKCAFVSG

3 RHYAGEVAYD TSGFLEKNRD LLHMDSIQLL AKCKISLPKM FASKMLVQSD

$6011<--V 10-\cdots>$

650

1 LFPPLP.QET AKSSKFSSIG SRFKLQLQSL METLSSTEPH YIRCVKPNNL 2 LFPFLS.EDS SKSSKFSSIG SRFKQQFQSL LETLSATEPH YIRCVKPNNL 3 NSMSVPYRSS AADSQKLSVA MKFKGQLFQL MQRLESTTPH FIRCIKPNNL

$1<-V 11->1$

$|<-\cdot-v 12-\cdots>|$

750

1 VLEGSNDDKI ACOKILEKMG L.. ENYQIGK TKVFLRAGQM ADLDARRAEV 2 VLSGSSDEVS AVRRLLDKID L.. .QGYQIGK TKVFLRAGQM AELDARRNEV 3 DVA.SQDPLS VSVAILHQFN ILPEMYQVGY TKLFFRTGQI GNLEDTRNRT class II non-plant myosins, GgBBI and GgSM, respectively. Analysis of the tail regions resulted in a closer clustering of both classes of plant myosins.

\section{Immunodetection}

The affinity-purified M11L1 antibody bound to a single high molecular weight band on Western blots (Fig. 7). Analysis of fractions from differential centrifugation showed that the antigen was not evenly distributed among the organelles that comprised the initial homogenate (Fig. 7). The nuclear/cell wall fraction and the plastid fraction contained relatively small amounts of antigen. Most of the antigen was found in the mitochondrial fraction and the low density membrane fraction. Confocal analysis of these last two fractions using double labeling with the DNA stain propidium iodide and M11L1 showed that the antibody did not stain DNAcontaining organelles (data not shown).

Maize root tips were quite easy to section with the Vibratome, and we examined hundreds of sections from multiple immunocytochemical experiments. In root tip sections, there were no cell types that lacked reactivity with the M11L1 antibody (Fig. 8). Myosin XI was most prevalent in vacuolating epidermal corn root tip cells (Figs. 8, 9). The outermost root cap cells were brightly stained as well (Fig. 8). Within most cell types the antigen was solely distributed in a particulate pattern (Fig. 10). Neither the vacuole membrane nor the plasma membrane were stained. In vacuolating epidermal cells where the intensity of staining was highest (Fig. 11), it was impossible to unambiguously determine if the fluorescence originated from the plasma membrane, or from organelles adjacent to the plasma membrane, or both. The same was true in cortical cells located near the epidermis. In dividing cells, there was no concentration of myosin near either the spindle of mitotic cells (Fig. 10) or the forming cell plate (Fig. 12).

\section{DISCUSSION AND CONCLUSIONS}

\section{Maize Myosin Diversity}

Previous results obtained with immunological methods indicate that maize myosins with molecular weights of $95,110,160,180$, and $210 \mathrm{kDa}$ are present in

Fig. 5. Alignment of ZMM cDNA head sequences. The Multalin program was used. Amino acid residue numbering appears at the ends of each block. Blocks of sequence where no gaps occur have been omitted. Variable regions are defined by dots representing conceptual gaps where there are no ZMM3 amino acid residues that align with ZMM1 and ZMM2. Variable region numbering refers to the molecular model of chicken muscle myosin. The numbers $1,2,3$, (left) refer to ZMM1, 2, and 3, respectively. 

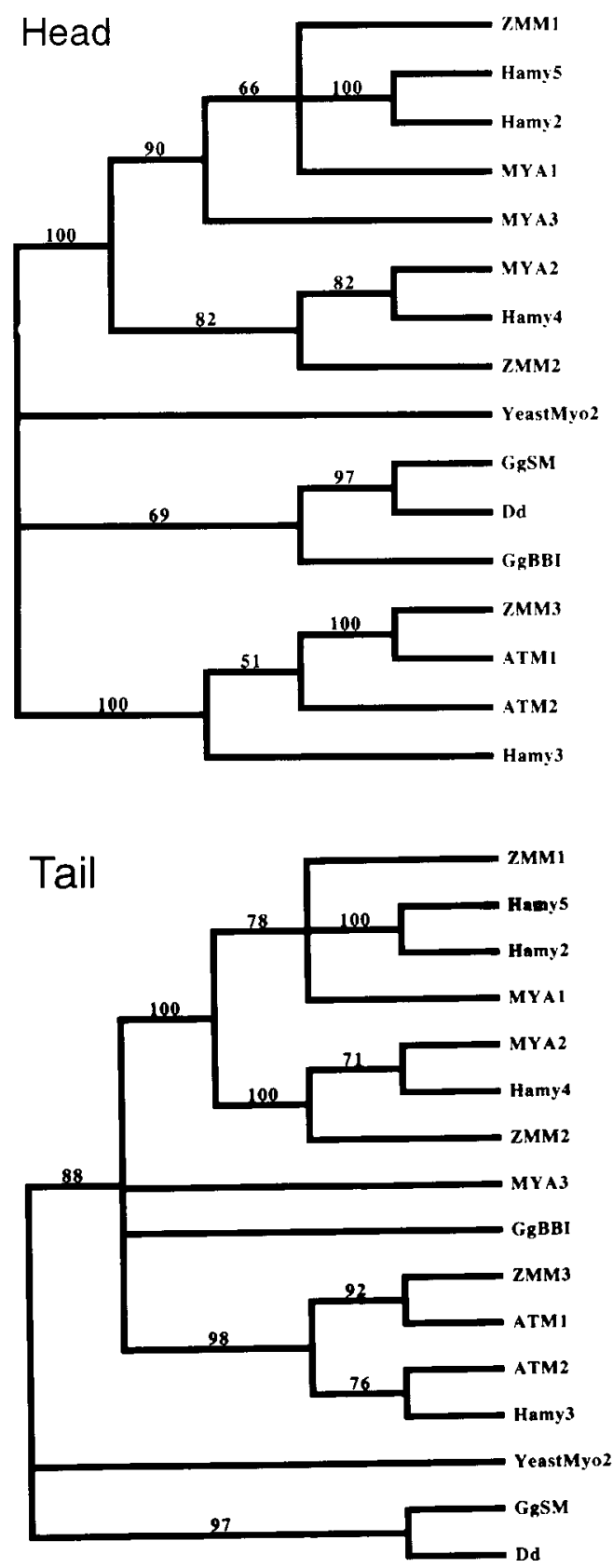

Fig. 6. Phylogenetic relationships among plant myosins. The trees were generated by computer program PAUP, version 3.1.1. Yeast Myo2 (Saccharomyces cerevisiae, Genbank accession no. P19524) was used as an outgroup member. The number at the branches indicates number of times the dichotomy was supported out of 100 bootstrap tries. Two rooted trees were generated using either the head or the tail cDNA coding sequences. In addition to ZMM1-3, other plant myosin sequences analyzed were Arabidopsis myosins ATM1, ATM2, MYA1, MYA2, and MYA3 and Helianthus myosins, Hamy2-5. Three nonplant myosins included in this analysis were: chicken brush border myosin I (GgBBI), chicken skeletal muscle myosin II (GgSM), Dictyostelium myosin II (Dd), and yeast Myo2. roots [Radford and White, 1998; Baluska et al., 2000]. Our results indicate that the molecular weights of Zea class XI myosins lie within a much more restricted range. The predicted molecular weights of ZMM1, ZMM2, and ZMM3 are $173.5,153.7$, and $124.4 \mathrm{kDa}$, respectively. The highest of these values agrees with the molecular weight seen on the Western blot (obtained using an antibody specific for myosin XI). Since the ZMM2 and ZMM3 clones have small portions of their $5^{\prime}$ ends missing, the full-length sequences will have slightly larger molecular weights than those values presented here.

The fact that only two classes of myosin were isolated from maize was an unexpected result. Yeast, an extensively studied organism that has the fewest classes of myosin of all nonplant organisms, has three classes of myosin, class I (Myo3 and Myo5), class II (Myo1p), and class V (Myo2p and Myo4p). While our examination of maize involved multiple attempts to find as many myosin sequences as possible, we were never able to find any that did not clearly fall into either Class VIII or XI.

\section{Functions}

The putative $\alpha$-helical regions found in the ZMM tails are much less extensive than those known to exist in class II myosins [for a review see Warrick and Spudich, 1987], and class II myosins typically have repeat units of 197 amino acids [McLachlan, 1984], which are not present in the ZMMs. Nevertheless, because repeat units of 7 residues form the basis of an amino acid $\alpha$-helix, ZMMs do have a limited potential

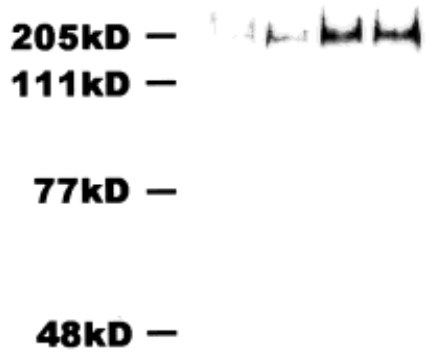

$34 k D$ -

\section{4}

Fig. 7. Presence of myosin XI in differential centrifugation pellets. Using affinity-purified antibody M11L1 as a probe, it was observed that myosin XI was concentrated in specific membrane fractions. Each lane was loaded with $4 \mu \mathrm{g}$ of protein. The nuclear/cell wall (Lane 1) and the plastid (Lane 2) pellets contained little myosin. The mitochondrial (Lane 3) and the low-density (Lane 4) pellets contained the most. Numbers (left) refer to the position of molecular weight markers. 

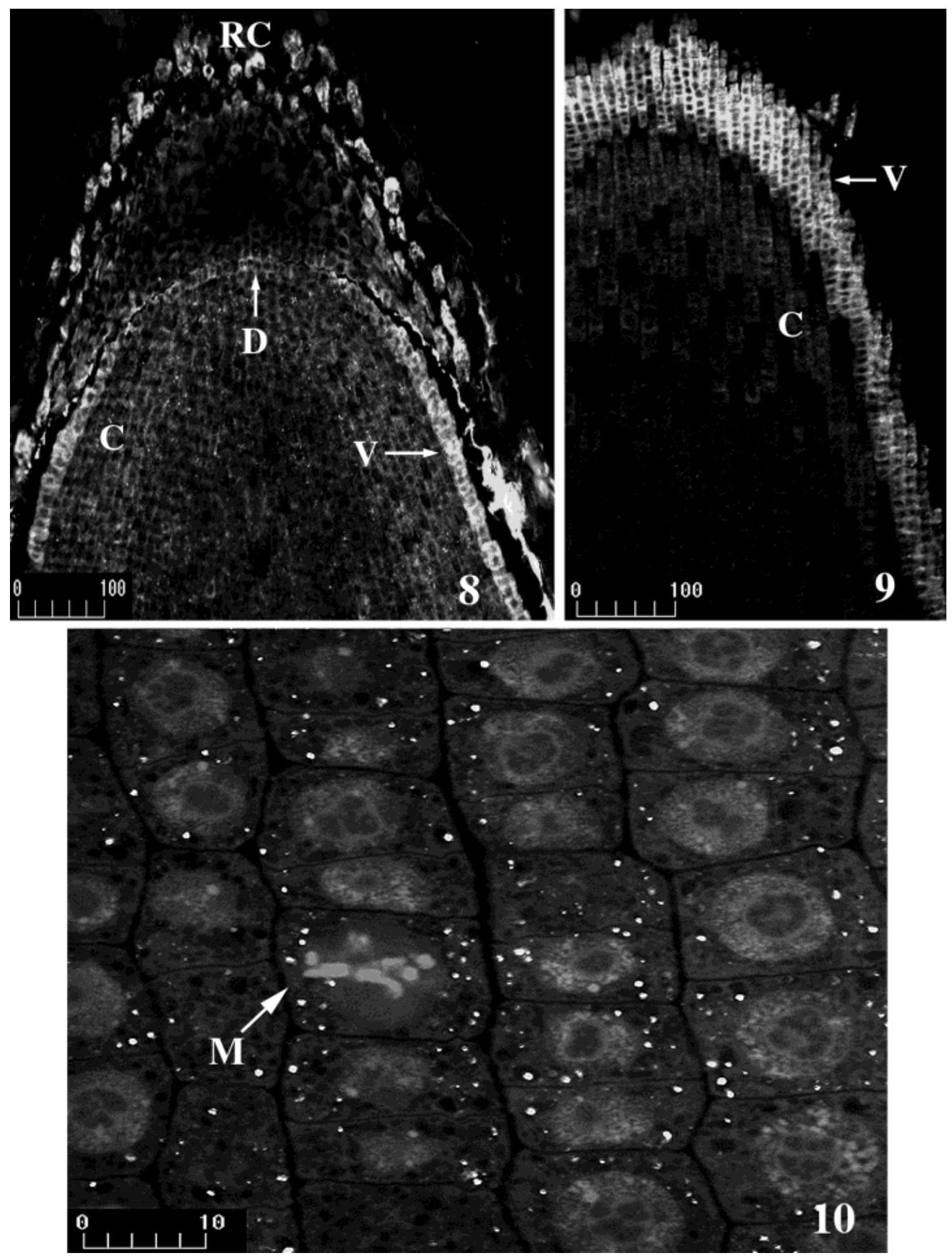

Fig. 8. Myosin XI in corn root tip cells near the apex. In this near median, longitudinal section not all cell types are equally labeled. The highest intensity of labeling is in the vacuolating epidermal cells (V) and the outermost root cap cells (RC). The dividing epidermal cells in the center of the root (D) are not as intensely labeled. $\mathrm{C}=$ cortical cells. Bar $=100 \mu \mathrm{m}$.

Fig. 9. Myosin XI in differentiating epidermal and cortical cells. In this slightly oblique tangential section, the difference in the staining of the epidermal cells, which are intensely labeled, and the cortical cells is quite obvious. $\mathrm{V}=$ vacuolating epidermal cells, $\mathrm{C}=$ cortical cells. Bar $=100 \mu \mathrm{m}$.
Fig. 10. Myosin XI in meristematic cortical cells. In this dual-labeled image, the low-intensity propidium iodide staining of nuclei and cytoplasm shows the overall cytology while the high-intensity spots show the location of myosin within each cell. The cell walls, which are the dark boundaries of each cell, are clearly unlabeled, as are the nuclei and the plasma membranes. The myosin is concentrated on or near numerous small vesicles in each cell. There does not appear to be any marked difference between the distribution of myosin in the interphase cells and in the single mitotic cell with condensed chromatin, which is located approximately in the center of the figure (M). Bar $=10 \mu \mathrm{m}$. 


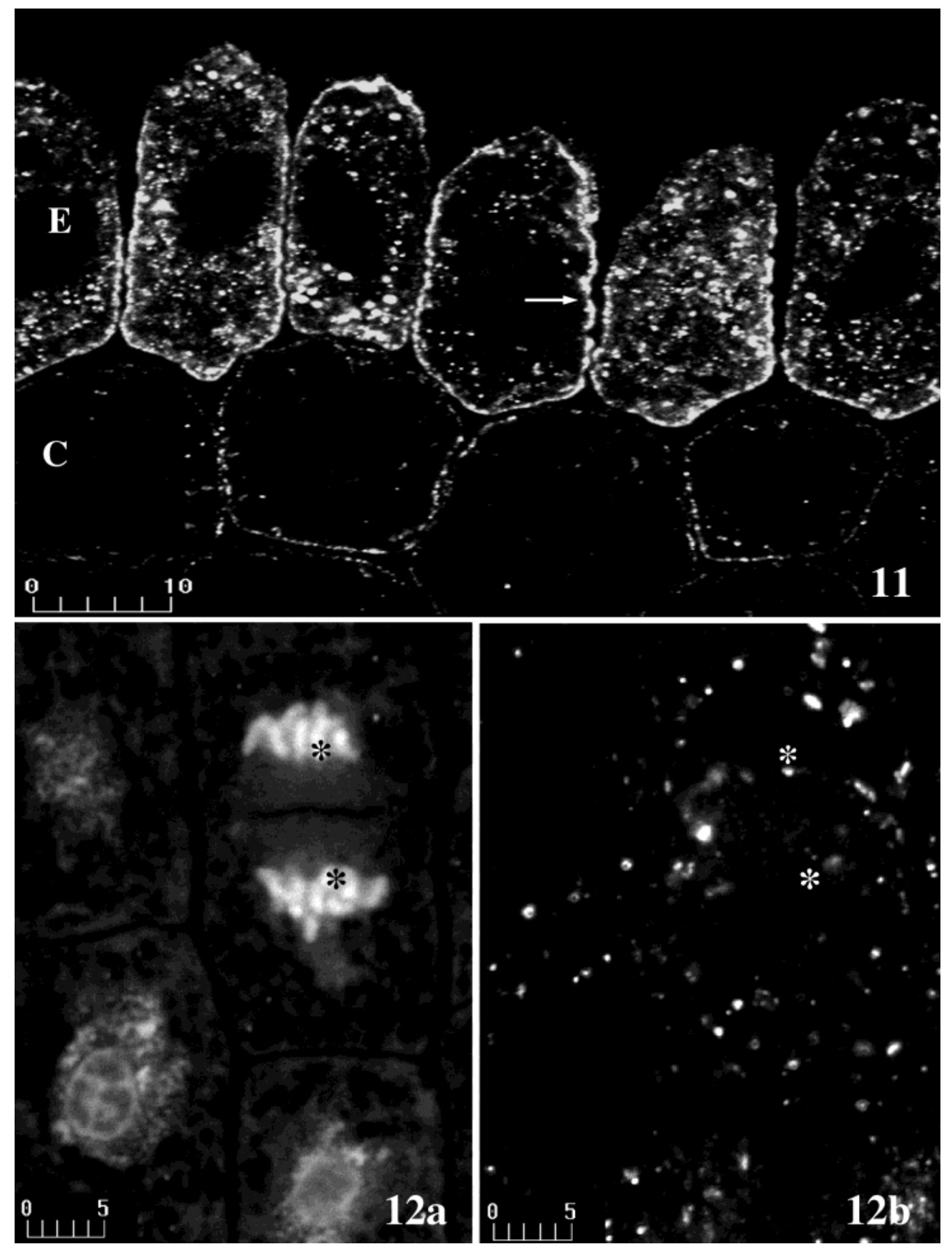

Fig. 11. Transverse section of vacuolating epidermal and cortical cells. The labeling within the vacuolating epidermal cells (E) is clearly greater than that within the adjacent cortical cells (C). The cell walls are not stained, and there is no continuous staining along the central vacuoles. The plasma membranes of the epidermal and cortical cells appear to be stained. In the cortical cells, the intensity of the staining along the plasma membrane appears as discrete dots, which could be due either to small organelles or to localized areas of myosin attached to the plasma membrane. Bar $=10 \mu \mathrm{m}$.
Fig. 12. Longitudinal section of a cell in cytokinesis. a: propidium iodide staining; b: M11L1 staining. Black asterisks in (a) mark the positions of the white asterisks in b. The partially formed cell plate is surrounded by particulate myosin. There is, however, no clear organization or area of concentration of the myosin. Instead, it appears that the myosin is evenly distributed throughout the cell except that it is excluded from areas containing condensed chromatin. Bar $=5 \mu \mathrm{m}$. 
to form molecular coils with alternating regions of charged/hydrophobic residues that might interact between heavy chains to form dimers or bipolar filaments. However, it is not clear if filaments exist in vivo and there is little information regarding the native molecular weight of plant myosin.

The observations of others [Kinkema et al., 1994] indicate that myosin XI shares a weak similarity $(\sim 40 \%)$ with yeast myosin $\mathrm{V}$ in the tail region. It has been shown in yeast and other organisms that myosin I is involved in membrane traffic, myosin $\mathrm{V}$ is used for vesicle transport, and myosin II produces forces for the formation of the contractile ring during cytokinesis and muscle contraction [Warrick and Spudich, 1987; Mermall et al., 1998]. This suggests that myosin XI may be specialized for vesicle transport in plant cells. In support of this role are the data from previous studies showing that the translocational step size produced by a myosin motor is proportional to the number of light chain binding domains (or IQ motifs) [Uyeda et al., 1996]. The fact that ZMM3 (a myosin VIII) has three IQ motifs while ZMM1 and ZMM2 (both myosin XIs) have six, indicates that the expected step size for myosin VIII and XI would be close to 15 and $30 \mathrm{~nm}$, respectively. A larger step size for myosin XIs could make them faster, or more efficient, vesicle transport motors.

Another important functional factor that distinguishes class VIII ZMM3 from both ZMM1 and ZMM2 is the 5 amino acid deletion in the ZMM3 V4 region. Several experiments have demonstrated that the rate of ADP release and sliding velocity are correlated with the flexibility and size of V4 [Kurzawa-Goertz et al., 1998; Sweeney et al., 1998]. Thus, it is likely that the ZMM3 moves at a slower rate and with a smaller step size than ZMM1 or ZMM2. In animals, unconventional myosins with larger step sizes are believed to be important for rapid transport of large vesicles [Mermall et al., 1998], again suggesting a role for myosin XI in vesicle transport.

One striking similarity among the ZMMs is the conservation of sequence length in the reigon that connects the GESGAGKT site with the IQ motif. This connecting region spans both the $25-50 \mathrm{kd}$ and the 50-20 kd junctions, regions that typically show little sequence or length similarity in many myosins. The ZMM connecting sequence may be similar to the "core domain" that has been noted for myosin II [Goodson and Spudich, 1993]. There is also evidence that light chains that bind to the heavy chain neck region are also very near the heavy chain ATP-binding site in vivo [Okamoto et al., 1986], suggesting that there may be functional constraints on the length of the connecting sequence.

\section{Evolution of Plant Myosins}

The sequence similarity data, the PAUP phylogenetic analysis, and the alignment data all support the conclusion that ZMM1 and ZMM2 resemble each other more than they do ZMM3, and that ZMM1 and ZMM2 belong to myosin class XI while ZMM3 is a member of myosin class VIII. These two classes of myosin have only been found previously in two dicotyledons, Helianthus annuus and Arabidopsis thaliana. The existence of two classes of myosin in both dicotyledons and monocotyledons suggests that the origin of these two classes predates the divergence of monocotyledons and dicotyledons, which is believed to have occurred 80-120 million years ago [Mauseth, 1998].

Our PAUP analyses offer clear support for the existence of subclasses within class XI, as has been suggested by Mooseker and Cheney [1995] in their review of the results of Kinkema et al. [1994]. Also, the presence of a conserved 23 amino acid sequence near the tail of ZMM1, Hamy5, and MYA1, all of which consistently form a subclass in our phylogenetic analyses, indicates that this sequence is diagnostic within class XI (Hamy2, also in the same group, does not have a complete tail sequence). In contrast, the analogous region in ZMM2 has no similarity to other myosins. This difference may reflect a divergence of function within class XI, with the ZMM1 subclass being functionally constrained so that it retains the diagnostic 23 amino acid sequence, but the ZMM2 subclass being used in functions that either have no specific sequence requirements or different requirements in that region. The tails of several animal myosins have sites for membrane binding and are responsible for targeting the myosins to specific sites [Pollard et al., 1991; Catlett and Weisman, 1998; Zang and Spudich, 1998]. Possibly, each of the two subclasses within class XI is responsible for the movement of a specific type of vesicle/membrane. Unfortunately, the tail sequences of plant myosins do not bear significant similarity to those of other known myosins so, at present, it is only apparent that the tails have evolved to meet plant-specific needs.

Previous studies that addressed diversity in the entire myosin family [Goodson and Spudich, 1993] indicated that there is a close relationship between the evolution of head and tail regions of myosin. Our data using either the head or the tail for construction of phylogenetic trees indicate that while the observations of Goodson and Spudich are valid within class VIII, they do not adequately describe the relationship between class VIII and other classes of plant myosin. The relationship of class VIII and class XI tails in the PAUP analysis is problematic given the low sequence similarity and the Southern blots that show that ZMM tails have diverged 
from each other at a more rapid rate than have the heads. Even given this divergence, the grouping of all the ZMM tails with those of the other higher plants into a single clade by the PAUP analysis suggests that at least some portions of the tail domain have evolved to fit a common constraint(s).

\section{Organ-Specific Expression of Myosin Genes}

The expression pattern data indicate that myosin transcripts were present in most tissues studied, although some preferential expression occurred. The great abundance of ZMM2 in fresh kernels is most striking. A number of highly specialized dynamic events in the endosperm such as segregation of syncytial cytoplasm and cell wall deposition involve the cytoskeleton [Olsen et al., 1992]. Thus, ZMM2 may play a unique role in endosperm development, which is not required in other portions of the plant.

Given the functional association between actin and myosin, it is interesting to note that plant actin genes have been found to cluster into vegetative and reproductive subfamilies [Meagher et al., 1999]. The results here with myosin are not so clear cut. ZMM2 is predominately expressed in seeds, and it would be interesting if the function of the C-terminal variable region was important in determining the site of myosin action in reproductive tissues. On the other hand, ZMM3 is not present in pollen, but does occur in seeds and silks, as well as in vegetative parts. Thus, while it is clear that the reproductive organs of maize have developed a specialized expression pattern for myosins, it is not yet clear that ZMM3, for example, can be thought of as a "reproductive tissue myosin." Such may be the case if several ZMM3-like genes are found to exist and be uniquely expressed in each organ or tissue.

Myosin has been immunolocalized in pollen of other species [Tirlapur et al., 1995] and has been detected in Northern blots of whole flowers of Arabidopsis [Kinkema et al., 1994], although no data were collected specifically for pollen. Our Northern analysis indicated that ZMM3, a maize myosin VIII, was not expressed in pollen although it was generally expressed in other tissues. While the reduced complexity of the male gametophyte may engender a reduced complexity in the repertoire of expressed myosins, it is difficult to conceive of a cell type that does not require myosin. These data may be an another indication that there is a specificity of use for ZMMs, although redundancy of use, as may be the case in other systems [Wessels et al., 1991], could exist and make the functional importance of this observation trivial.

\section{Cellular and Subcellular Localization}

A high concentration of myosin in a root tip epidermis has not been previously documented. From a broader perspective, we have found no previous reference to the preferential localization of a plant myosin within any plant organ with the exception of an article published during the revision of this manuscript [Baluska et al., 2000]. This is perhaps best understood in view of the fact that many immunolocalization studies of myosin have involved the use of more easily accessible cell types such as pollen tubes [see Miller et al., 1995 and references therein] or algae [see Grolig et al., 1988; La Claire et al., 1995 and references therein]. The epidermis is a distinct tissue, both in structural and developmental terms, and so it is not difficult to understand that a specific isoform of myosin could be differentially expressed there. In contrast to our results, Baluska et al. used a heterologous antibody to the entire bovine muscle myosin molecule. They reported that maize root phloem elements were the most reactive cell type.

Myosin has been unambiguously linked to cleavage furrow formation in animal cells [Fujiwara and Pollard, 1976]. In plants there have been reports of myosin concentrated in the cytokinetic apparatus of plants [Parke et al., 1986]. Reichelt et al. [1999] used an antibody against the tail of Arabadopis class VIII myosin and noted an association with the post-cytokinetic apparatus. After an extensive effort on our part to detect an association of myosin XI with some aspect of cytokinesis, we have to conclude that, while myosin XI is present in the cytoplasm adjacent to the developing cell plate, it is no more prevalent there than it is in the other areas of the cytoplasm. Neither is myosin XI organized into any array that would be indicative of an essential function for the protein in cell division. Thus, our results differ from those of Parke et al. [1986] who found "strong labeling" of the cytokinetic phragmoplast. This raises the overall question of how plant myosin is involved in cytokinesis.

There is reason to suspect that cytokinesis in plants and animals may have vastly different molecular requirements. Most obviously, the entire structure and developmental sequence of cytokinesis in the two groups is significantly different. Plants lack a contractile ring, instead having what might be termed a centrifugal disk (the cell plate). Another factor to consider is that although actin has been associated with plant cytokinesis, its function there is unclear and need not involve myosin. At present, it is still possible that either another class of myosin is closely associated with plant cytokinesis, or that myosin need not be concentrated near the phragmoplast to perform its function there.

What is obvious from our results is that the general cytoplasmic distribution of myosin XI is dramatically different from that of myosin VIII. Reichelt et al. [1999] found myosin VIII associated predominantly with end walls and postulated that it anchors F-actin near plasmodesmata. Their finding indirectly supports the hypoth- 
esis that it is myosin XI that is specialized for vesicle transport. In light of the distinct sequence differences that we have shown exist in the $\mathrm{C}$-terminal regions of myosin XIs, it seems likely that these regions may code for attachment to specific types of membranes.

Our results are the first to clearly show the presence of plant myosin in a conventional "low-density membrane fraction." In previously published studies, Reichelt et al. [1999] and Baluska et al. [2000] used centrifugation at $13,800 \mathrm{~g}$ for $50 \mathrm{~min}$ to produce a "membrane-bound protein fraction" pellet from corn roots. Reichelt et al. used this pellet for Western blots and concluded that myosin VIII was associated with membranes at the postcytokinetic cell wall. It has been our experience and that of others (see references cited in our Materials and Methods), that this amount of centrifugal force is not sufficient to pellet a "low-density membrane fraction" that would include the plasma membrane, Golgi vesicles, and endoplasmic reticulum.

Our immunocytochemistry and differential centrifugation results show that myosin XI is associated with a distinct subset of organelles. The particulate distribution of myosin epitopes within plant cells has been previously noted for several plant species [Radford and White, 1998, and references cited therein]. Using antibodies generated against animal myosin epitopes Miller et al. [1995] reported that specific size classes of organelles in sections bound different myosin antibodies. The association of maize root tip myosin XI with only the mitochondrial and low-density membrane fractions, and the lack of such staining in the plastid and nuclear/cell wall fractions, is in agreement with Miller et al. [1995] who studied myosin distribution in pollen tubes. They observed that myosin V (which myosin XI resembles) was associated with smaller organelles, but only myosin I was associated with nuclei and the plasma membrane. Our observation that there are numerous organelles in the maize root tip mitochondrial fraction that do stain with propidium iodide but do not stain with M11L1 indicates that myosin XI is not tightly associated with mitochondria. The myosin XI staining detected in the mitochondrial pellet could be due to other types of membranes.

Given the limitations of the differential centrifugation technique and the immunofluorescence technique, the most straightforward conclusion that can be drawn from our data is that the endoplasmic reticulum membranes and/or some other class of small vesicles are associated with myosin XI in corn root tips. This is in agreement with the earlier mentioned data showing that myosin XI is similar to myosin V (which is involved in vesicle transport), and has a relatively large step size.

\section{ACKNOWLEDGMENTS}

This research was partially supported by a Competitive Research Grant (R-637) from the State of Louisiana Educational Quality Support Fund to T.C.P.

\section{REFERENCES}

Altschul SF, Gish W, Miller W, Dyers EW, Lipman DJ. 1990. Basic local alignment search tool. J Mol Biol 215:403-410.

Asada T, Collings D. 1997. Molecular motors in higher plants. Trends Plant Sci 2:29-37.

Ausubel FM, Brent R, Kingston RE, Moore DD, Seidman JG, Smith JA, Strul K. 1988. Current protocols in molecular biology. New York: John Wiley \& Sons. p 2.4.1.

Baluska F, Polsakiewicz M, Peters M, Volkmann D. 2000. Tissuespecific subcellular immunolocalization of a myosin-like protein in maize root apices. Protoplasma 212:137-145.

Bonner, J. 1976. Cell and subcell. In: Bonner J, Varner JE, editors. Plant biochemistry. New York: Academic Press, p 3-14.

Burgos RC, Chiang VL, Zhang X.-H, Campbell ER, Podila GK, Campbell WH. 1995. RNA isolation from plant tissue recalcitrant to extraction in guanidine. BioTechniques 19:734-737.

Burnett WV. 1997. Northern blotting of RNA denatured in glyoxal without buffer circulation. BioTechniques 22:668-671.

Cai G, Moscatelli A, Del Casino C, Cresti M. 1996. Cytoplasmic motors and pollen tube development. Sex Plant Reprod 9: $59-64$.

Catlett NL, Weisman LS. 1998. The terminal tail region of a yeast myosin- $\mathrm{V}$ mediates its attachment to vacuole membranes and sites of polarized growth. Proc Natl Acad Sci USA 95:14799147804.

Chomczynski P, Sacchi N. 1987. Single-step method of RNA isolation by acid guanidinium thiocyanate-phenol-chloroform extraction. Anal Biochem 162:156-159.

Cope MJTV, Whisstock J, Rayment I, Kendrick-Jones J. 1996. Conservation within the myosin motor domain: implications for structure and function. Structure 4:969-987.

Corpet F. 1988. Multiple sequence alignment with hierarchical clustering. Nucleic Acids Res 16:10881-10890.

Dellaporta SL, Wood J, Hicks JB. 1983. A plant DNA minipreparation: Version II. Plant Mol Biol Rep 1:19-21.

Espreafico EM, Cheney RE, Matteoli M, Nascimento AA, De Camilli PV, Larson RE, Mooseker MS. 1992. Primary structure and cellular localization of chicken brain myosin-V (p190), an unconventional myosin with calmodulin light chains. J Cell Biol 119:1541-1557.

Frohman KB, Dush M, Marlin G. 1988. Rapid amplification of fulllength cDNAs from rare transcripts: amplification using a single-specific oligonucleotide primers. Proc Natl Acad Sci USA 85:8998-9002.

Fujiwara K, Pollard TD. 1976. Fluorescent antibody localization of myosin in the cytoplasm, cleavage furrow and mitotic spindle of human cells. J Cell Biol 71:848-875.

Goodson HV, Spudich JA. 1993. Molecular evolution of the myosin family: relationships derived from comparisons of amino acid sequences. Proc Natl Acad Sci USA 90:659-663.

Grolig F, Williamson RE, Parke J, Miller C, Anderton BH. 1988. Myosin and $\mathrm{Ca}^{2+-}$ sensitive streaming in the alga Chara: detection of two polypeptides reacting with a monoclonal antimyosin and their localization in the streaming endoplasm. Eur J Cell Biol 47:22-31. 
Haarer, BK, Petzold A, Lillie SH, Brown SS.1994. Identification of MYO4, a second class V myosin gene in yeast. J Cell Sci 107:1055-1064.

Halsall DJ, Hammer JA III. 1990. A second isoform of chicken brush border myosin I contains a 29-residue inserted sequence that binds calmodulin. FEBS Lett 267:126-130.

Hayashida M, Maita T, Matsuda G. 1991. The primary structure of skeletal muscle myosin heavy chain. J Biochem 110:54-59.

Joshi CP, Zhou H, Huang X, Chiang VL. 1997. Context sequences of translation initiation codon in plants. Plant Mol Biol 35:9931001.

Kashiyama T, Kimura N, Mimura T, Yamamoto K. 2000. Cloning and characterization of a myosin from Characean alga, the fastest motor protein in the world. J Biochem 127:1065-1070.

Kinkema M, Schiefelbein J. 1994. A myosin from a higher plant has structural similarities to class V myosins. J Mol Biol 239: 591-597.

Kinkema M, Wang H, Schiefelbein J. 1994. Molecular analysis of the myosin gene family in Arabidopsis thaliana. Plant Mol Biol 26:1139-1153.

Knight AE, Kendrick-Jones J. 1993. A myosin-like protein from a higher plant. J Mol Biol 231:148-154.

Kurzawa-Goertz SE, Perreault-Micale CL, Trybus KM, Szent-Gyorgyi AG, Geeves MA. 1998. Loop I can modulate ADP affinity, ATPase activity, and motility of different scallop myosins. Transient kinetic analysis of S1 isoforms. Biochemistry 37: $7517-7525$.

La Claire II JW, Chen R, Herrin DL. 1995. Identification of a myosinlike protein in Chlamydomonas reinhardtii (Chlorophyta). J Phycol 31:302-306.

Liebe S, Quader H. 1994. Myosin in onion (Allium cepa) bulb scale epidermal cells: involvement in dynamics of organelles and endoplasmic reticulum. Physiol Planta 90:114-124.

Lupas A, VanDyke M , Stock J. 1991. Predicting coiled coils from protein sequences. Science (Wash DC) 252:1162-1164.

Ma YZ, Yen LF. 1989. Actin and myosin in pea tendrils. Plant Physiol 89:586-589

Mauseth JD. 1998. Botany, an introduction to plant biology. Sudbury: Jones and Bartlett Publishers. p 712.

McLachlan AD. 1984. Structural implications of the myosin amino acid sequence. Ann Rev Biophys Bioeng 13:167-189.

McLachlan AD, Karn J. 1982. Periodic charge distributions in the myosin rod amino acid sequence match cross- bridge spacings in muscle. Nature (Lond) 299:226-231.

Meagher RB, McKinney EC, Vitale AV. 1999. The evolution of new structures: clues from plant cytoskeletal genes. Trends Genet $15: 278-284$

Mermall V, Post PL, Mooseker MS. 1998. Unconventional myosins in cell movement, membrane traffic, and signal transduction. Science (Wash DC) 279:527-533.

Miller DD, Scordilis SP, Hepler PK. 1995. Identification and localization of three classes of myosins in pollen tubes of Lilium longiflorum and Nicotiana alata. J Cell Sci 108:2549-2563.

Moepps B, Conrad S, Schraudolf H. 1993. PCR- dependent amplification and sequence characterization of partial cDNAs encoding myosin-like proteins in Anemia phyllitidis (L) Sw and Arabidopsis thaliana (L) Heynh. Plant Mol Biol 21: 1077-1083.

Mooseker MS, Cheney RE. 1995. Unconventional myosins. Annu Rev Cell Dev Biol 11:633-675.

Nehez, R, Fazekas S, Ovary I, Szekessy-Hermann V. 1985. Purification and some properties of myosin prepared from root tips of maize seedlings. Acta Agron Acad Sci Hung 34:267-273.
Okamoto Y, Sekine T, Grammar J, Yount RG. 1986. The essential light chains constitute part to the active site of smooth muscle myosin. Nature 324:78-80.

Olsen OA, Potter RH, Kalla R. 1992. Histo-differentiation and molecular biology of developing cereal endosperm. Seed Sci Res 2:117-131.

Or E, Boyer SK, Larkins BA. 1993. opaque2 Modifiers act posttranscriptionally and in a polar manner on r-zein gene expression in maize endosperm. Plant Cell 5:1599-1609.

Parke J, Miller C, Anderton BH. 1986. Higher plant myosin heavychain identified using a monoclonal antibody. Eur J Cell Biol 41:9-13.

Pelle R, Murphy NB. 1993. Northern hybridization: rapid and simple electrophoretic conditions. Nucleic Acids Res 21: 2783-2784.

Pieson ES, Cresti M. 1992. Cytoskeleton and cytoplasmic organization of pollen and pollen tubes. Int Rev Cytol 140:97-140.

Plazinski J, Elliott J, Hurley UA, Burch J, Arioli T, and Williamson RE. 1997. Myosins from angiosperms, ferns, and algae amplification of gene fragments with versatile PCR primers and detection of protein products with a monoclonal antibody to a conserved head epitope. Protoplasma 196:78-86.

Pollard TD, Korn ED. 1973. Acanthamoeba myosin. J Biol Chem 248:4682-4690.

Pollard TD, Doberstein SK, Zot HG. 1991. Myosin I. Ann Rev Physiol 53:653-681.

Radford JE, White RG. 1998. Localization of a myosin-like protein to plasmodesmata. Plant J 14:743-750.

Rayment IH, Rypniewski WR, Schmidt-Base K, Smith K, Tomchick DR. 1993. Three-dimensional structure of myosin subfragment-1: a molecular motor. Science 261:50-58.

Reichlelt S, Knight AE, Hodge TP, Baluska F, Samaj J, Volkmann D, Jones JK. 1999. Characterization of the unconventional myosin VIII in plant cells and its localization at the post-cytokinetic cell wall. Plant J 19:555-567

Reizes O, Barylko B, Li C, Sudhof TC, Albanesi JP. 1994. Domain structure of a mammalian myosin I beta. Proc Natl Acad Sci USA 91:6349-6353.

Rickwood D, Ford T, Steensgard J. 1994. Centrifugation, essential data. Chichester, UK: John Wiley and Sons Ltd. p 26-27.

Sambrook J, Frisch EF, Maniatis T. 1989. Molecular cloning: a laboratory manual, 2nd ed. Cold Spring Harbor, NY: Cold Spring Harbor Laboratory.

Sanger F, Neckline S, Calcine AR. 1977. DNA sequencing with chain-terminating inhibitors. Proc Natl Acad Sci USA 74: 5463-5467.

Schmidt AC, Lambert AM. 1990. Microinjected fluorescent phalloidin in vivo reveals the F-actin dynamics and assembly in higher plant mitotic cells. Plant Cell 2:129-138.

Sellers JR. 2000. Myosins: a diverse superfamily. Biochem Biophys Acta 1496:3-22.

Staiger CJ, Lloyd NW. 1991. The plant cytoskeleton. Curr Open Cell Biol 3:33-42.

Sweeney HL, Rosenfeld SS, Brown F, Faust L, Smith J, Xing J, Stein LA, Sellers JR. 1998. Kinetic tuning of myosin via a flexible loop adjacent to the nucleotide binding pocket. J Biol Chem 273:6262-6270.

Swofford DL. 1994. PAUP: phylogenetic analysis using parsimony. Version 311. Champaign, IL: Illinois Natural History Survey.

Tirlapur UK, Cai G, Faleri C, Moscatelli A, Scali M, Del Casino C, Tiezzi A, Cresti M. 1995. Confocal imaging and immunogold electron microscopy of changes in distribution of myosin dur- 
ing pollen hydration, germination and pollen tube growth in Nicotiana tabacum L. Eur J Cell Biol 67:209-217.

Uyeda TQ, Abramson PD, Spudich JA. 1996. The neck region of the myosin motor domain acts as a lever arm to generate movement. Proc Natl Acad Sci USA 93:4459-4464.

Vahey M, Titus M, Trautein R, Scordilis S. 1982. Tomato actin and myosin: contractile proteins from a higher land plant. Cell Motil Cytoskeleton 2:131-147.

Wang L-F, Voysey R, Yu M. 1994. Simplified large-scale alkaline lysis preparation of plasmid with minimal use of phenol. BioTechniques 17:26-28.

Warrick HM, Spudich JA. 1987. Myosin structure and function in cell motility. Annu Rev Cell Biol 3:379-421.
Wessels D, Murray J , Jung G, Hammer JA III, Soll DR. 1991. Myosin IB mutants of Dictostylium exhibit abnormalities in motility. Cell Motil Cytoskeleton 20:301-315.

Williamson RE. 1993. Organelle movements. Annu Rev Plant Physiol Plant Mol Biol 44:81-202.

Yamamoto K, Kikuyama M, Sutoh-Yamamoto N, Kamitsubo E, Katayama E. 1995. Myosin from alga Chara: unique structure revealed by electron microscopy. J Mol Biol 254:109-112.

Yokota E, Shimmen T. 1994. Isolation and characterization of plant myosin from pollen tubes of lily. Protoplasma 117:153-162.

Zang JH, Spudich JA. 1998. Myosin II localization during cytokinesis occurs by a mechanism that does not require its motor domain. Proc Natl Acad Sci USA 95:13652-13657. 